Arculus, R.J., Ishizuka, O., Bogus, K., and the Expedition 351 Scientists, 2015

Proceedings of the International Ocean Discovery Program Volume 351

publications.iodp.org

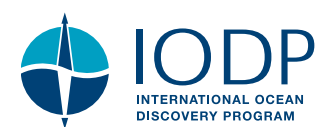

\title{
Contents
}

doi:10.14379/iodp.proc.351.101.2015

\section{Expedition 351 summary ${ }^{1}$}

CrossMark \&lick for updates

R.J. Arculus, O. Ishizuka, K. Bogus, M.H. Aljahdali, A.N. Bandini-Maeder, A.P. Barth, P.A. Brandl, R. do Monte Guerra, L. Drab, M.C. Gurnis, M. Hamada, R.L. Hickey-Vargas, F. Jiang, K. Kanayama, S. Kender, Y. Kusano, H. Li, L.C. Loudin, M. Maffione, K.M. Marsaglia, A. McCarthy, S. Meffre, A. Morris, M. Neuhaus, I.P. Savov, C.A. Sena Da Silva, F.J. Tepley III, C. van der Land, G.M. Yogodzinski, and Z. Zhang ${ }^{2}$

Keywords: International Ocean Discovery Program, IODP, JOIDES Resolution, Expedition 351, Site U1438, Izu Bonin Mariana, arc origins, subduction initiation, Earth connections, Amami Sankaku Basin, Kyushu-Palau Ridge, basalt, volcanic ash, breccia-conglomerate, biostratigraphy, magnetostratigraphy, oceanic crust, arc basement, Neogene, Paleogene, foraminifers, radiolarians, volcaniclastic, back arc, tuffaceous mud, hemipelagic, East Asian Monsoon, subduction factory

\section{Abstract}

The intraoceanic Izu-Bonin-Mariana (IBM) arc in the western Pacific has been intensively examined over the past few decades, and the outlines of its overall tectonic and magmatic history have been revealed. Arc inception occurred at $\sim 52 \mathrm{Ma}$, concurrent with a major change in the motion of the Pacific plate. Rifting of the active volcanic axis took place at $\sim 25 \mathrm{Ma}$, with accompanying seafloor spreading and eastward migration of the active volcanic front forming a volcanically inactive remnant arc (Kyushu-Palau Ridge; KPR). The Amami Sankaku Basin (ASB) flanks the northern KPR; the ASB seafloor has a simple structure comprising $\sim 1.5 \mathrm{~km}$ of sediment overlying igneous oceanic crust. International Ocean Discovery Program Expedition 351 targeted the ASB, anticipating recovery of the sedimentary record of the earliest stages of arc inception and evolution of the northern IBM arc. Igneous basement samples would permit determination of the petrological, geochemical, and age characteristics of the pre-KPR crust in the region, from which the geochemical composition of the mantle prior to IBM arc inception and growth could be inferred.

The expedition successfully accomplished its primary and most of its secondary objectives at Site U1438 in $4700 \mathrm{~m}$ water depth. Drilling penetrated $1461 \mathrm{~m}$ of sediment and $150 \mathrm{~m}$ of variably altered and veined aphyric to sparsely phyric tholeiitic basalt lava flows, which form the uppermost igneous oceanic basement (lithostratigraphic Unit 1). Four sedimentary units have been established in the sedimentary column above basement, described here from oldest to youngest. Lithostratigraphic Unit IV $(99.7 \mathrm{~m})$ consists of early Eocene mudstone, tuffaceous siltstone, breccia-conglomerate, sandstone, and radiolarian-bearing mudstone. The oldest radiolarian age is 50-53 Ma (Section 351-U1438E-63R-1; $40 \mathrm{~m}$ above basement), and the oldest foraminifer age is less than $57.8 \mathrm{Ma}$ (Section 351-U1438E-66R-CC; $12 \mathrm{~m}$ above basement). Lithostratigraphic Unit III (1046 m) consists of Eocene-Oligocene tuffaceous mudstone, tuffaceous sandstone, sandstone with gravel, and breccia-conglomerate with pebble/cobble-sized volcanic and sedimentary rock clasts. Lithostratigraphic Unit II $(139.4 \mathrm{~m})$ is Oligocene tuffaceous mudstone, siltstone, and fine sandstone with localized slumping. Lithostratigraphic Unit I (160.3 m) is latest Oligocene to recent, mud and ooze of terrigenous and biogenic origin, with interspersed discrete tephra layers.

In addition to fossil age constraints, in situ downhole temperature measurements and thermal conductivity measurements on core material from Unit I give a calculated heat flow of $73.7 \mathrm{~mW} / \mathrm{m}^{2}$, implying a thermal age for the underlying lithosphere of 40-60 Ma. The recovery at Site U1438 of an extensive sediment sequence of early Eocene age in Unit IV, coeval with the putative initiation of the IBM arc at $~ 52$ Ma determined by radiometric dating of fore-arc igneous samples, will allow comprehensive analysis of the provenance, geochemical and petrological characteristics, and style of earliest arc magmatic activity in the KPR. The geochemical and petrological equivalence of the Unit 1 lava flows with the "fore-arc basalts" of the IBM fore arc has critical implications regarding the style of magmatism accompanying arc initiation and the lateral (across-strike) extent of this type of igneous activity. The apparent absence of boninite at Site U1438, however, may indicate petrologic provinciality was established within the first few million years of IBM magmatism.

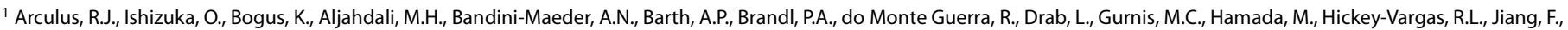
Kanayama, K., Kender, S., Kusano, Y., Li, H., Loudin, L.C., Maffione, M., Marsaglia, K.M., McCarthy, A., Meffre, S., Morris, A., Neuhaus, M., Savov, I.P., Sena Da Silva, C.A., Tepley, F.J., III, van der Land, C., Yogodzinski, G.M., and Zhang, Z., 2015. Expedition 351 summary. In Arculus, R.J., Ishizuka, O., Bogus, K., and the Expedition 351 Scientists, Proceedings of the International Ocean Discovery Program, Expedition 351: Izu-Bonin-Mariana Arc Origins: College Station, TX (International Ocean Discovery Program). http://dx.doi.org/10.14379/iodp.proc.351.101.2015

2 Expedition 351 Scientists' addresses.

MS 351-101: Published 25 August 2015
} 
The voluminous volcaniclastic rocks recovered from the Eocene through Oligocene sequence of Units II, III, and IV contain sufficiently fresh glass (at least in the shallower section) and igneous minerals and clasts to allow comprehensive petrological and geochemical description of the compositional evolution during the Paleogene IBM arc. A noteworthy feature of the mineral assemblage is the persistent but minor occurrence of amphibole. This phase is rare in the tephra recovered from previously drilled sites in the IBM fore arc and may indicate that significant across-strike variability of magma compositions was established in the Paleogene.

Formation MicroScanner images show bedding and other features that may help characterize the large-scale tectonic development of the ASB; structural orientation may characterize the geographic provenance of the coarse-grained sediments. Sonic and density data from logs and cores will give a seismic traveltime-depth relationship for the site, providing characterization of seismic boundaries and accurate tie-points between core-log data and seismic data. The seismic velocity structure of the ASB specifically and the adjacent KPR more generally will become better constrained.

The quality of the cores obtained in the uppermost Unit I provide an excellent paleoceanographic sedimentary record, including the Oligocene-Miocene transition, the mid-Miocene climatic optimum, and the Pliocene-Pleistocene onset of Northern Hemisphere glaciation and mid-Pliocene transition. Numerous layers of volcanic ash were recovered in the recent to Miocene sediments of Unit I, comprising vitric pumice and shards, as well as phenocrysts and isolated volcanogenic crystals of pyroxene, plagioclase, biotite, quartz, and opaque minerals. Comparison of glass and mineral compositions with Ryukyu-Kyushu, Honshu, and Neogene IBM tephras will permit identification of the sources of volcanic ash; pending further age constraints, new data from Site U1438 will permit refined modeling of volumes, explosivity, and geochemical properties of the explosive output of the respective arcs surrounding the ASB.

The fundamentally important discoveries of the age (>50 Ma based on biostratigraphy; $<60 \mathrm{Ma}$ thermal age) and composition of the oceanic basement at Site U1438 provide critical constraints on the inception of the intraoceanic IBM arc. It appears a major change in Pacific plate motion following subduction of the Izanagi-Pacific Ridge beneath East Asia led to reorganization of equatorially located networks of island arc systems in the region between the Australian and Asian plates. The Philippine Sea plate developed in this region and experienced trench roll-back at one or more of its bounding plate margins. Rotation of the Philippine Sea plate led to propagation of transpressional forces on its northeastern margin, accompanied by rifting and seafloor spreading invading the former arc edifices forming much of the oldest part of the plate. Localization of a defined volcanic front in the IBM arc developed as the Philippine Sea plate migrated northward, and the transpressional boundary rotated clockwise to orthogonality with the westwardsubducting Pacific plate. The oldest magmatic basement of the IBM arc developed in a latitudinally and longitudinally extensive seafloor spreading regime and is dominated by tholeiitic magmas sourced from highly depleted upper mantle.

\section{Introduction}

The formation and destruction of lithospheric plates is a fundamentally important process leading to the creation of the most important Earth surface features and a major driver of planetary physical and chemical evolution. Subduction zones marking sites of plate destruction are unique to Earth among the terrestrial planets, but as yet, we do not have a good understanding of how they are initiated beyond the recognition that old (older than $\sim 25 \mathrm{Ma}$ ) ocean lithosphere is gravitationally unstable with respect to the underlying asthenospheric mantle. Given the pull of subducting plates is widely regarded as the primary driver of the kinematics of plate tectonics, the initiation of subduction zones is a geological problem of the first order.

Ignorance of subduction and arc initiation contrasts with our relatively advanced level of understanding of oceanic crust creation from initial lithospheric rifting to development of a mid-ocean ridge. There are a number of locations on the surface of the Earth where the "rift to drift" sequence can be explored, such as the AfarRed Sea region of northeastern Africa, the northernmost extension of the Mid-Atlantic Ridge in the Arctic Ocean, or a number of backarc basins in the western Pacific such as the Lau, North Fiji, and Manus Basins. In contradistinction, locations where the earliest stages of subduction and arc initiation can be studied are comparatively few.

Subduction at a zone of plate convergence requires resisting forces (thrust fault friction, $F_{\mathrm{f}}$, and elastic plate bending, $F_{\mathrm{el}}$ ) be overcome by the sum of driving forces (plate tectonic forces, $F_{\mathrm{pt}}$, and the slab's negative buoyancy, $F_{\mathrm{s}}$; Hall et al., 2003):

$$
F_{\mathrm{s}}+F_{\mathrm{pt}}>F_{\mathrm{f}}+F_{\mathrm{el}}
$$

On the basis of the assumed ages of the current major subduction systems bordering the Pacific and along the Alpine-Himalayan Zone, McKenzie (1977) suggests that "ridges start easily, but trenches do not." Endorsing this view, Mueller and Phillips (1991) point out the absence of any example in the geological record of the transformation of an Atlantic-type (passive) into an Andean-type (active) margin, despite the negative buoyancy of the oldest oceanic lithosphere adjacent to the continental lithosphere at passive margins. On the other hand, Gurnis et al. (2004) point out that about half of all active subduction zones initiated in the Cenozoic in a variety of tectonic settings including old fracture zones, transform faults, extinct spreading centers, and through polarity reversals behind active subduction zones; they conclude subduction initiation is commonplace where the resisting forces are overcome through the normal evolution of plate dynamics.

A number of authors have suggested the most likely sites for subduction initiation are transform faults, primarily as a consequence of a change in relative plate motions (e.g., Uyeda and BenAvraham, 1972; Casey and Dewey, 1984). A localized cause such as arrival of relatively buoyant slices of continental lithosphere or an oceanic plateau at a trench are examples of triggers for such relative motion changes (e.g., Wallace et al., 2009); the subduction polarity reversal along the former Vitiaz Trench between the Pacific and Australian plates with the arrival of the Ontong Java Plateau represents the latter case (Hall, 2002; Crawford et al., 2003). But the causes of far-field effects, such as the change in Pacific plate motion at $\sim 50$ Ma representing the possible trigger for inception in the IzuBonin-Mariana (IBM) arc system, are less readily accounted for (Whittaker et al., 2007) and highlight the 3-D aspect of the overall problem of subduction initiation.

The processes accompanying subduction initiation are identified as part of Challenge 11 of the Science Plan of the International Ocean Discovery Program (IODP; available at www.iodp.org/science-plan-for-2013-2023). Initiation may occur in a variety of ways depending on relative plate strengths and ages and the plate 
tectonic driving mechanism (Gurnis et al., 2004; Leng et al., 2012). Among a number of proposed hypotheses, two general mechanisms seem particularly relevant to initiation of the IBM system, one of the largest, nominally intraoceanic subduction zones in the western $\mathrm{Pa}$ cific. These general mechanisms are induced or spontaneous (Figure F1) (Gurnis et al., 2004; Stern, 2004). Induced subduction initiation leading to self-sustaining descent of lithosphere into the mantle results from a convergence forced by external factors such as ridge push or slab pull along strike of a given system (e.g., Gurnis et al., 2004). Outboard stepping (e.g., incipient plate boundary south of India; Sykes, 1970) or polarity reversal (e.g., Solomon Islands) may develop. Stern (2004) resuscitated the hypothesis of differential buoyancy and suggested the IBM system represents an example of spontaneous initiation wherein subsidence of relatively old Pacific lithosphere commenced along a system of transform faults/fracture zones adjacent to relatively young, buoyant lithosphere. Foundering of the old lithosphere is predicted to induce asthenospheric upwelling in an extensional regime forming boninites and eventually forearc ophiolites (Stern and Bloomer, 1992). The initial record on the overriding plate should be clear: in the most basic terms, induced subduction likely results in strong compression and uplift potentially shedding debris into nearby basins, whereas spontaneous subduction initiation occurs without uplift or shedding of sediment but rather basement deepening prior to rifting, spreading, and formation of magmas in an extensional setting, potentially analogous to a number of ophiolites (e.g., Gurnis et al., 2004).

Following subduction initiation, evolving magmatism is fundamental to the creation of an island arc, which in turn is essential to the formation and evolution of continental crust, at least through the Phanerozoic (Davidson and Arculus, 2006). The earliest magmatic stages of island arcs have recently been identified in the current fore arcs of the IBM arc system (Mariana: Reagan et al., 2010; Izu-Bonin: Ishizuka et al., 2011a) and the Central American arc (Buchs et al., 2010). In the case of the former, a suite of low-K, midocean-ridge basalt (MORB)-like tholeiitic magmas were erupted for a period of $\sim 4 \mathrm{My}$, followed by boninites for a similar duration. The tholeiitic suite has been termed "fore-arc basalt" (FAB) by Reagan et al. (2010). Subsequent development of the IBM system apparently reverted to eruptive tholeiitic activity focused at a volcanic front, with possibly more K-rich magmas behind the volcanic front. In the case of Central America, Buchs et al. (2010) identified a MORB-like, low-K tholeiitic suite with minimal large ion lithophile element enrichments as the initial magmatic stage of the arc system in the Late Cretaceous; they termed this suite "proto-arc." A normal arc tholeiitic suite was among the volcanic products subsequently erupted, but no boninites have been recognized.

Accretion of arc welts to continental margins with accompanying structural, metamorphic, and magmatic modifications are arguably the most important processes for continuing continental crust evolution. For many trace and minor elements, the continental crust is quantitatively important despite its volumetric insignificance on a planetary scale. Among all the terrestrial magma types, those of relatively selective trace element-enriched island arcs are uniquely similar to continental crust in terms of lithophile trace element abundances (Taylor, 1967). Specific overlap in terms of absolute abundances of intermediate arc andesites ( 52-63 wt\% $\left.\mathrm{SiO}_{2}\right)$ and the bulk intermediate silica content of the continental crust led Taylor (1967) to propose the "andesite" model for formation of this crustal type.

Testing models of subduction initiation and subsequent arc evolution requires identification and exploration of regions adjacent to an arc, where unequivocally pre-arc crust (basement) overlain by undisturbed pre-arc and/or arc-derived materials can be recovered. An essential boundary condition for understanding arc evolution and continental crust formation is to know the composition, structure, and age of the crust and mantle that existed before subduction began. This condition derives from the fact that in addition to slabderived components (e.g., volatiles and fluid-mobile trace elements), the mantle wedge and overriding plate are important and in some cases volumetrically dominant contributors to the magmas that form the arc. Determining the net contributions from the mantle wedge and subducted and overriding plates to the magmas forming the arc through time requires that we know the geochemical characteristics of these individual components.

Figure F1. Schematic diagram of induced versus spontaneous subduction initiation models (adapted from Stern, 2004).

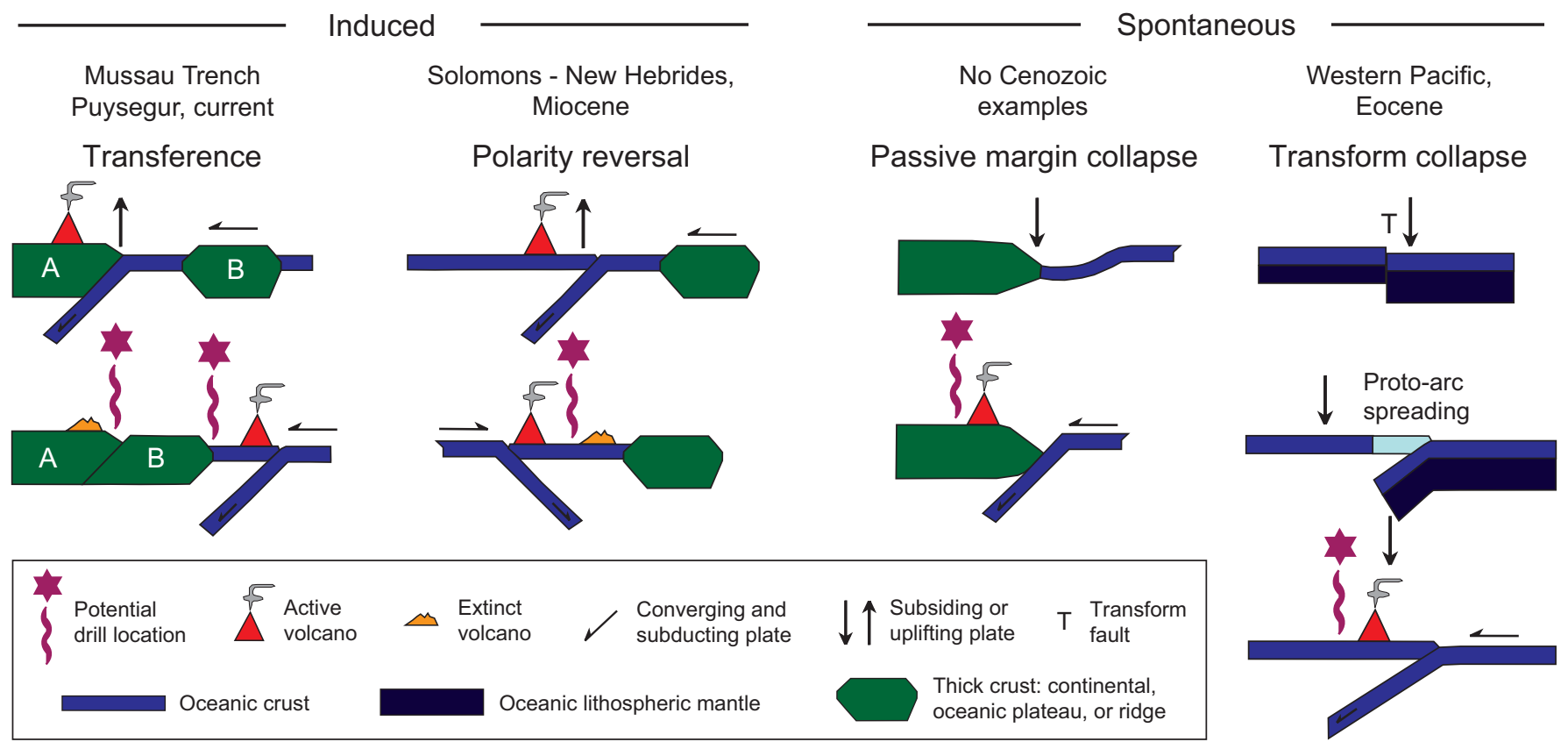


The IBM system is globally important because there is clear evidence for the age ( 52 Ma; Ishizuka et al., 2011a) and exact site (Kyushu-Palau Ridge [KPR]) of inception, duration of arc activity, and changes in magmatic composition through time through extensive drilling (ash and pyroclast records) and dredging. The nature of the sum product of prolonged magmatic activity has also been constrained by seismically determined crustal structure. It is possible to identify the oceanic basement on and into which the initial arc products following subduction initiation were emplaced. For most arc systems, the age of initiation is unknown and the basement is obscured and/or deeply buried. For the IBM system, a region has been identified in the Amami Sankaku Basin (ASB) where the prearc basement foundations of the nascent arc could be investigated (Figure F2); the overlying sediment preserves evidence of the initiation and subsequent evolution of the arc, particularly through the first $\sim 25$ My of its history.

There were two primary targets for IODP Expedition 351: the oceanic basement and the overlying sedimentary sequence. Recovering oceanic basement samples allowed us to determine the age and petrological and geochemical characteristics of the pre-KPR crust, from which the geochemical composition of the mantle prior to IBM arc initiation can be determined. Overlying the basement is $\sim 1460 \mathrm{~m}$ of sediment, in which evidence is preserved for the timing

Figure F2. Philippine Sea region. Izu-Bonin and Mariana arcs and associated trenches form the eastern boundary of the Philippine Sea plate. The western boundary includes the Ryukyu-Kyushu and Philippine arcs and trenches. Back-arc basins such as the Shikoku Basin, Parece Vela Basin, and Mariana Trough were created by seafloor spreading between the formerly contiguous remnant arc (Kyushu-Palau and West Mariana Ridges) and eastwardmigrating active volcanic arcs, now represented by the Izu-Bonin and Mariana arcs. Pink star in Amami Sankaku Basin = Site U1438. Smaller pink star in eastern West Philippine Basin = ODP Site 1201.

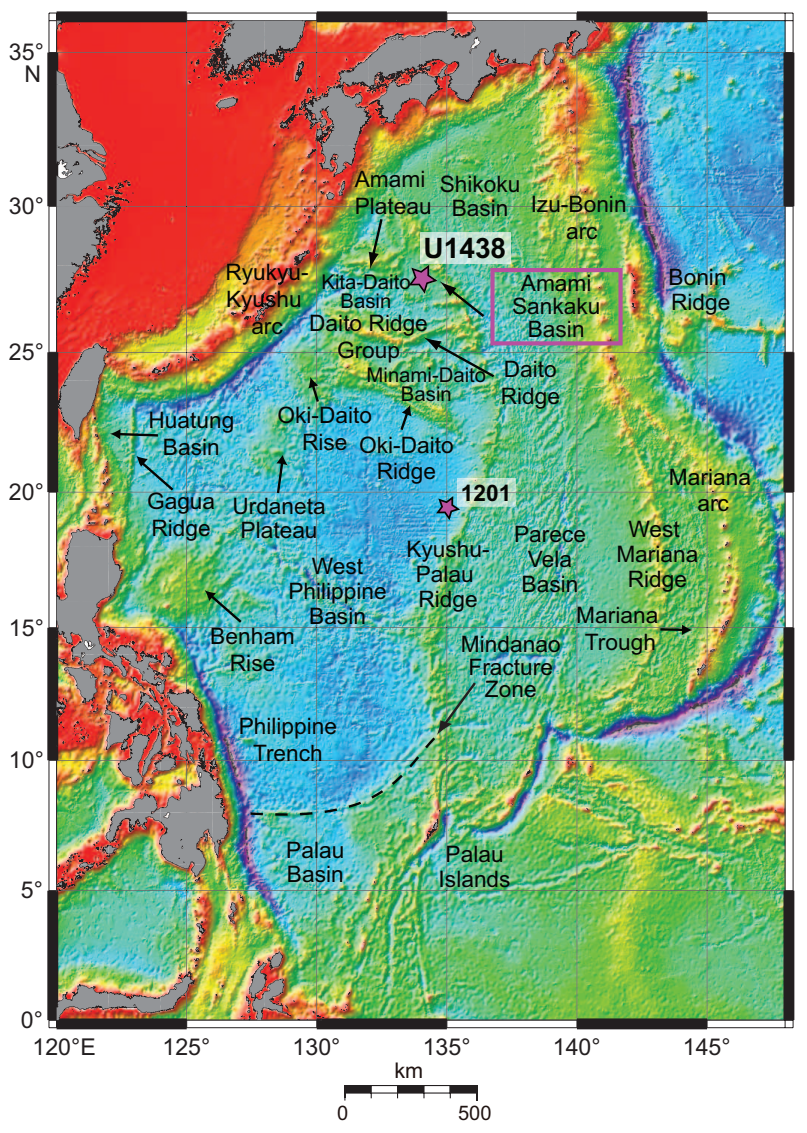

and processes associated with subduction initiation. Different responses of the overriding plate during the initial stages of subduction initiation are predicted to result from either induced (uplift) or spontaneous initiation of the subduction zone. Shallower in the sedimentary section, the explosive ash and pyroclastic fragmental records for at least the first $\sim 27 \mathrm{My}(\sim 52-25 \mathrm{Ma})$ of the developing KPR are preserved. This record diminishes in intensity and volume following the formation of the Shikoku Basin and eastward migration of the active arc volcanic front. To date, the geochemical data available for these kinds of materials recovered from the fore-arc regions of the IBM system are concentrated in the Neogene (e.g., Straub, 2003), so the thick Paleogene record from the ASB is complementary and significant for resolving the early history of the arc.

The IBM system is an ideal location for tackling the global challenges of understanding subduction initiation and early evolution of an arc given the wealth of scientific data collected for the system and the potential preservation of critical sites where, by drilling alone, critical records of these fundamental Earth processes can be recovered. We know that an immense strike length of intraoceanic subduction systems was initiated at $\sim 50 \mathrm{Ma}$ in the western and northern Pacific, likely accompanying global plate reorganization at this time (Sharp and Clague 2006; Seton et al., 2012). In addition to the IBM system, the Tonga-Kermadec and Aleutian arc systems appear also to have formed at this time. Although the current geochemical characteristics of the Tonga arc are similar to those of IBM, others, such as the Aleutians, seem persistently geochemically and geophysically distinct. Given this diversity, we know the investigation of arc initiation and evolution is a burgeoning field of study. The IBM system is a well-constrained, representative end-member of the diversity of arc systems where we can commence this effort. In order to understand the processes of inception and subsequent evolution of the IBM arc however, its own history in the context of the geological and tectonic development of the region in which the arc is located are fundamentally important. In the following sections, summaries are presented of our state of knowledge in these respects.

\section{Background and setting Regional setting}

The western part of the Philippine Sea plate (PSP), where Site U1438 is located, is complex both topographically and geologically; the following features are highlighted in Figure F2: (1) the Early Cretaceous (131-119 Ma) Huatung Basin (Deschamps et al., 2000); (2) Gagua Ridge; (3) conjugate plateaus of possible hotspot origin Benham Rise and Urdaneta Plateau, now separated by (4) oceanic crust comprising the West Philippine Basin (WPB); (5) Mesozoic remnant arcs (Amami Plateau and Daito and Oki-Daito Ridges); (6) the possible "ocean island" or "hot-spot" related Oki-Daito Rise (Ishizuka et al., 2013); and (7) the Eocene-Oligocene KPR. Basins occur between the ridges in the northwest Philippine Sea, including (1) the Kita-Daito Basin, between the Amami Plateau and Daito Ridge; (2) the Minami-Daito Basin, between the Daito and OkiDaito Ridges; (3) the ASB; and (4) east of the KPR, the Shikoku Basin.

\section{Generalities}

\section{Regional considerations}

The PSP, Earth's eleventh largest lithospheric plate, is surrounded by subduction zones and transform faults and has a complex tectonic and magmatic history. The most comprehensive and 
recent plate tectonic reconstructions (Deschamps and Lallemand, 2002; Whittaker et al., 2007; Seton et al., 2012) adopt subduction inception at $\sim 50 \mathrm{Ma}$ in the proto-Izu-Bonin arc (KPR), concurrent with a change in Pacific plate motion, cannibalizing former northwest-southeast-trending transform faults associated with the Izanagi-Pacific Ridge (Figure F3). In essence, this is a revised version of the original hypothesis for subduction initiation specifically proposed for the IBM system by Uyeda and Ben-Avraham (1972), of convergence across a transform fault following plate reorganization. Izanagi-Pacific Ridge subduction was the last stage in the development through the Mesozoic of closure between the Australian plate to the south and Asia to the north, resulting in subduction along the Asian continental margin of a series of formerly linked spreading ridges from the Indian through to the Pacific Ocean (Seton et al., 2012). Whittaker et al. (2007) propose subduction of the IzanagiPacific Ridge along much of eastern Asia at $\sim 60 \mathrm{Ma}$ initiated the reorganization of plate motions that culminated in the change in motion of the Pacific plate at $50 \mathrm{Ma}$ relative to the Eurasian plate. Of course, the original extent of the PSP is not known, as much has been subducted along the Nankai Trough and the Ryukyu and Philippine Trenches. But the areal extent of the PSP has also been augmented by creation of new back-arc basin oceanic crust generated through seafloor spreading in the West Philippine, Shikoku, and Parece Vela Basins and the Mariana Trough. An additional aspect of reconstruction is that the PSP has undergone northward migration mostly between 50 and $25 \mathrm{Ma}$, accompanied by clockwise rotation approaching $90^{\circ}$, since inception (Yamazaki et al., 2010; Richter and Ali, 2015).

At KPR inception, a Cretaceous-age island arc system existed, presently preserved as the Amami Plateau-Daito-Oki Daito Ridges; there may have been an arc conjugate on the other flank of the WPB spreading center, now accreted to Luzon (Deschamps and Lallemand, 2002). Lewis et al. (1982) had previously proposed the WPB is a back-arc basin developed north of the East Mindanao-Samar arc. The relationship of the Izanagi-Pacific Ridge to this arc system is unclear but critical in terms of understanding the nature of the basement of the KPR in the vicinity of the Amami PlateauDaito-Oki Daito Ridges and the history of Site U1438. Deschamps and Lallemand (2002) invoke northward subduction of oceanic lithosphere north of Australia beneath a late Mesozoic-Cenozoic eastwest-striking arc. Back-arc spreading north of this arc formed the

Figure F3. Oceanic crustal age grids at 55 and $45 \mathrm{Ma}$, after Whittaker et al. (2007). Black arrows $=$ motion of the Pacific plate $(\mathrm{mm} / \mathrm{y})$ relative to fixed African hotspot reference frame. WPB $=$ West Philippine Basin, IBM = IzuBonin-Mariana arc.

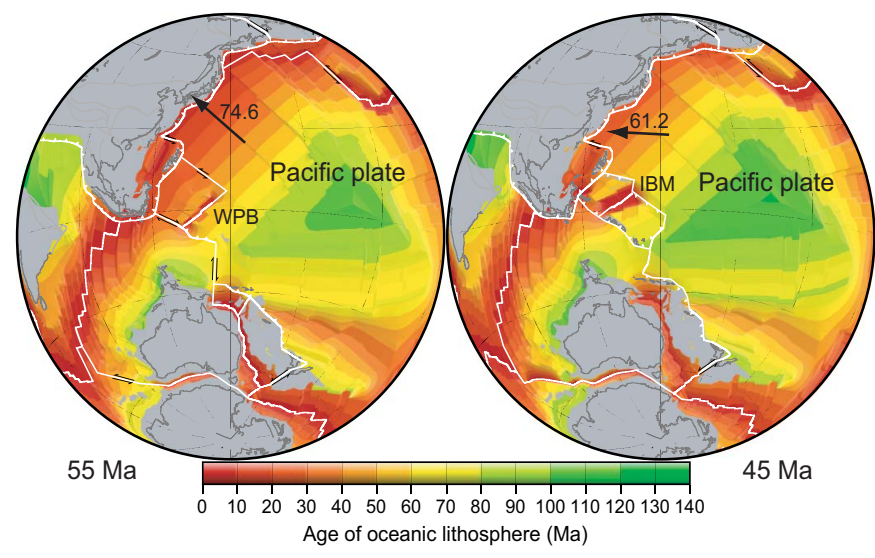

initial stages of the WPB, split the Amami Plateau-Daito-Oki Daito Ridges from the arc front in the south, and left these ridges as a remnant arc. Coincidentally and possibly critical in initiation of spreading in the WPB was ocean island basalt (OIB)-like magmatism, preserved as the Benham Rise-Urdaneta Plateau conjugates and the Oki Daito Rise. The source of this compositional type of magmatism may have been the Manus Basin hotspot (Macpherson and Hall, 2001; Ishizuka et al., 2013). Whittaker et al. (2007), on the other hand, proposed development of a southeastward ridge jump as the Izanagi-Pacific Ridge was consumed; the linking transform bypassed the Amami Plateau-Daito Ridge to join the WPB spreading center and subsequently itself became cannibalized to form the proto-IBM arc.

\section{Specifics}

\section{Huatung Basin-Gagua Ridge}

Amphibole separated from gabbros dredged from the western flank of the Gagua Ridge give ${ }^{40} \mathrm{Ar} /{ }^{39} \mathrm{Ar}$ ages of $116-121 \mathrm{Ma}$; in combination with interpretation of magnetic anomalies, Deschamps et al. (2000) conclude the Huatung Basin formed between 131 and $127 \mathrm{Ma}$ and suggest the oceanic crust underlying a sediment cover formed at a Cretaceous spreading ridge or back-arc basin. They further suggest the Gagua Ridge is a transpressional ridge between relatively old oceanic crust of the Huatung Basin and the younger WPB.

\section{Mesozoic remnant arcs (Daito Ridge group) and hotspot- related volcanic rocks (Oki-Daito Rise, Urdaneta Plateau, and Benham Rise)}

The Daito Ridge group is a complex array of ridges and basins. The group comprises three remnant arcs: the Amami Plateau, the Daito and Oki-Daito Ridges, and two basins neighboring these ridges (the Kita-Daito and Minami-Daito Basins) (Figure F2). Granites and arc volcanics of Cretaceous age (e.g., Matsuda et al., 1975; Hickey-Vargas, 2005) are exposed on the Amami Plateau, which has crustal thickness up to $19 \mathrm{~km}$ (Nishizawa et al., 2014). Geochemical characteristics of the volcanic rocks are consistent with formation of the plateau by Cretaceous-aged subduction zone magmatism (Hickey-Vargas, 2005). These remnant arcs predate the inception of IBM arc magmatism at $52 \mathrm{Ma}$ (Ishizuka et al., 2006a, 2011a).

The Daito Ridge is generally east-west trending and intersects the KPR at its eastern end (Figure F2). Low-grade metamorphic rock, sedimentary rock, and some volcanic rock were recovered by dredging, apparently from beneath Eocene sedimentary rock (Mizuno et al., 1975, 1978; Yuasa and Watanabe, 1977), whereas recent shallow drilling recovered fresh volcanic rock from the eastern part of the Daito Ridge. Two of these drilled samples (andesites) with the distinctive trace element characteristics of arc magmas yielded ${ }^{40} \mathrm{Ar} /{ }^{39} \mathrm{Ar}$ ages of 116.9 and 118.9 Ma (Ishizuka et al., 2011b). Both of these ages are significantly older than the KPR volcanism. These results revealed that the Daito Ridge comprises Mesozoic arc rock overlain by middle Eocene sedimentary rock (e.g., Mizuno et al., 1978).

The Oki-Daito Ridge is WNW-ESE trending and $\sim 600 \mathrm{~km}$ long. This ridge is characterized by crust ranging from 20 to $25 \mathrm{~km}$ in thickness, based on its seismic velocity structure (Nishizawa et al., 2014). A wide bathymetric high west of the Oki-Daito Ridge is the Oki-Daito Rise, which occupies an area of $\sim 60,000 \mathrm{~km}^{2}$; dredged rocks have intraplate ocean island geochemical characteristics and were probably formed through the same hotspot magmatism responsible for the Urdaneta Plateau-Benham Rise (Ishizuka et al., 
2013). All of these samples have to varying extents $\mathrm{Pb}$ isotopic characteristics of the "enriched mantle 2" (EM-2)-type source. The eastern margin of the rise appears to overlap the western part of the Oki-Daito Ridge. The rise is characterized by much thinner crust (10-15 km) compared to the neighboring Oki-Daito Ridge. Ishizuka et al. (2013) suggest the age-progressive volcanism from $\sim 50$ to 35 $\mathrm{Ma}$, becoming younger toward the WPB from the Minami-Daito Basin, is consistent with a hotspot origin.

The Kita-Daito Basin separates the Amami Plateau and the Daito Ridge and contains irregularly shaped seamounts and ridges. The Minami-Daito Basin is located between the Daito and OkiDaito Ridges. This basin has many more bathymetric highs compared to the Kita-Daito Basin, including conical seamounts. Drilling at Deep Sea Drilling Project (DSDP) Site 446 in the western part of the basin recovered basalt sills with ${ }^{40} \mathrm{Ar} /{ }^{39} \mathrm{Ar}$ plateau ages of 51.3 and 42.8 Ma (Hickey-Vargas, 1998a). These basalts are geochemically varied with tholeiitic and alkaline compositions and clearly have OIB-like geochemical characteristics (Hickey-Vargas, 1998a).

\section{West Philippine Basin}

The WPB is an ocean basin occupying the western half of the PSP (Figure F2). The Ryukyu and Philippine Trenches mostly bound the western margin of the basin. Between these trenches, the Gagua Ridge separates the WPB from the Cretaceous-age Huatung Basin. Prominent bathymetric features in the WPB include the broad highs of the Benham Rise and the Urdaneta Plateau. These features are located approximately equidistant from the Central Basin fault (CBF), which is an extinct spreading center. The Benham Rise was drilled on its southeastern flank at DSDP Site 292. A thick plagioclase-porphyritic basalt layer was recovered from beneath Eocene-early Oligocene sediment (Karig, Ingle, et al., 1975). Hickey-Vargas (1998b) reported ${ }^{40} \mathrm{Ar} /{ }^{39} \mathrm{Ar}$ ages of 35.6 and $36.2 \mathrm{Ma}$ for this basalt and OIB-like geochemical characteristics. The Urdaneta Plateau has dimensions of about $300 \mathrm{~km} \times 200 \mathrm{~km}$ and consists of two bathymetric highs, with seafloor fabrics similar to overlapping spreading centers or dueling propagators (Deschamps et al., 2008) and ${ }^{40} \mathrm{Ar} /{ }^{39} \mathrm{Ar}$ ages between 35.87 and $39.79 \mathrm{Ma}$ (Ishizuka et al., 2013). These oceanic plateaus within and north of the WPB form age-progressive volcanic chains that are hypothesized to have been produced by a mantle plume that remained fixed at the spreading center for $\sim 10$ My (Ishizuka et al., 2013).

The origin of the WPB has long been debated. Hilde and Lee (1984) published magnetic lineation data for this area (Figure F4A). Based on these data, they propose that spreading from a center co-

Figure F4. History of the West Philippine Basin (WPB). A. Interpretation of magnetic anomalies of the WPB (Hilde and Lee, 1984); figure modified after Deschamps et al. (2002). Chron 25 corresponds to $\sim 57 \mathrm{Ma}$; Chron 13 corresponds to $33 \mathrm{Ma}$. B. Schematic tectonic history for the Oki-Daito province and WPB, from Ishizuka et al. (2013). C. Evolutionary model of the WPB at $50 \mathrm{Ma}$ (adapted from Deschamps and Lallemand, 2003). D. Paleogeodynamic reconstruction of the western Pacific after Jolivet et al. (1989), based on the "trapped basin model" for generation of the WPB. AP = Amami Plateau, DR = Daito Ridge, EM-2 = enriched mantle 2, OIB = ocean island basalt, $\mathrm{CBF}=$ Central Basin Fault, $\mathrm{OD}=$ Oki-Daito Ridge, PAC/AUS = Pacific plate/Australian plate.
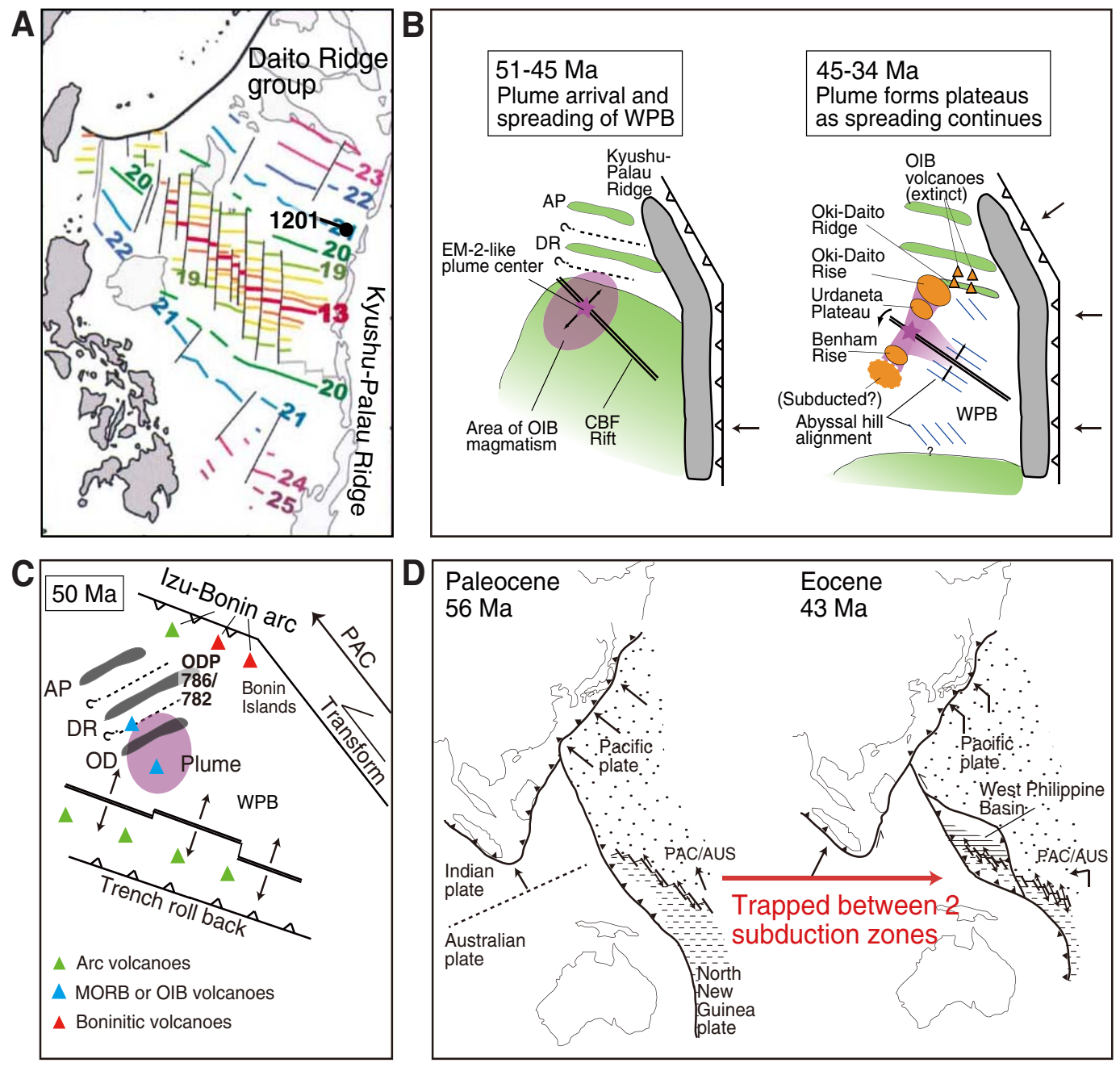
incident with the present-day CBF Rift formed the WPB. A spreading direction for the WPB was determined to be northeastsouthwest between 60 and $45 \mathrm{Ma}$ at a rate of $44 \mathrm{~mm} / \mathrm{y}$. After $45 \mathrm{Ma}$, the spreading direction changed to a more north-south direction associated with a reconfiguration of the Central Basin spreading center, and the spreading rate decreased to $18 \mathrm{~mm} / \mathrm{y}$. The major phase of spreading is inferred to have finished at $235 \mathrm{Ma}$. Other suggestions for the origin of the WPB include that of Lewis et al. (1982), who propose the basin formed as a back-arc basin behind the east Mindanao-Samar arc, and Seno and Maruyama (1984), who suggest the WPB formed behind the KPR. The hypothesis that the WPB is of back-arc origin has been further developed by recent studies (Figure F4B, F4C) (e.g., Fujioka, et al., 1999; Deschamps and Lallemand, 2002, 2003; Okino and Fujioka, 2003) based on new detailed bathymetric and geomagnetic data mainly acquired around the CBF Rift and the northern part of the basin, and further refined by Sasaki et al. (2014) based on new data collected in the southern part of the basin. Combined with the notion that subduction initiation of the IBM arc was contemporaneous with or preceded the opening of the WPB, Hall et al. (1995), Hall (2002), and Deschamps and Lallemand (2002) propose models assuming the WPB opened between the two subduction zones of the East Philippine and IBM arcs, followed by clockwise rotation of the latter. Deschamps and Lallemand (2002) further propose rifting started at $55 \mathrm{Ma}$ and spreading ended at 33-30 Ma. The spreading axis was parallel to the East Philippine arc but became inactive when a new spreading ridge propagated from the eastern part of the basin. Spreading of the basin occurred mainly from this new axis, which rotated counterclockwise during its existence.

An old hypothesis for the origin of the WPB is the so-called "trapped basin" model (Figure F4D) (e.g., Uyeda and Ben-Avraham, 1972). Le Pichon et al. (1985) propose the extinct spreading center of the WPB was a remnant of the North New Guinea-Kula spreading ridge that was captured at $43 \mathrm{Ma}$. Jolivet et al. (1989) present a similar but modified model, arguing the WPB is a remnant of the Pacific-North New Guinea spreading ridge captured at $43 \mathrm{Ma}$ by inception of a new subduction zone (i.e., the IBM) along a transform fault. More recent globally constrained plate tectonic reconstructions have established the Izanagi-Pacific spreading ridge was regionally important and do not confirm a role for the putative North New Guinea-Kula Ridge (Whittaker et al., 2007; Seton et al., 2012). Nevertheless, these more recent plate configurations also assume a trapped basin model in that the lithosphere north of the spreading center of the WPB was formerly part of the Izanagi plate.

\section{Kyushu-Palau Ridge}

The KPR forms the eastern margin of the WPB. It is now a remnant arc separating the WPB from the Shikoku and Parece Vela back-arc basins (Figure F2). The KPR was an active arc in the Eocene and Oligocene (e.g., Mizuno et al., 1977; Shibata et al., 1977; Ishizuka et al., 2011b) and became isolated from the volcanic front of the IBM arc at $\sim 25 \mathrm{Ma}$ through the initiation of rifting and seafloor spreading in the Shikoku and Parece Vela Basins (Ishizuka et al., 2011b). The CBF Rift, marking the extinct spreading center of the WPB, is truncated by the KPR at $\sim 15^{\circ} \mathrm{N}$. Radiometric ages for samples collected from the northern to central KPR range in age between 43 and $25 \mathrm{Ma}$ but are mostly between 27 and $25 \mathrm{Ma}$, indicating arc volcanism ended on the KPR at about this time (Figure F5). In other words, back-arc rifting (or spreading) of the Shikoku and Parece Vela Basins initiated at $25 \mathrm{Ma}$ (Ishizuka et al., 2011b). This interpretation is generally consistent with the estimated timing of rifting and spreading of the Shikoku Basin based on magnetic
Figure F5. Distribution of ${ }^{40} \mathrm{Ar} /{ }^{39} \mathrm{Ar}$ ages (Ma) for volcanic rocks from the Kyushu-Palau Ridge area (after Ishizuka et al., 2011b).

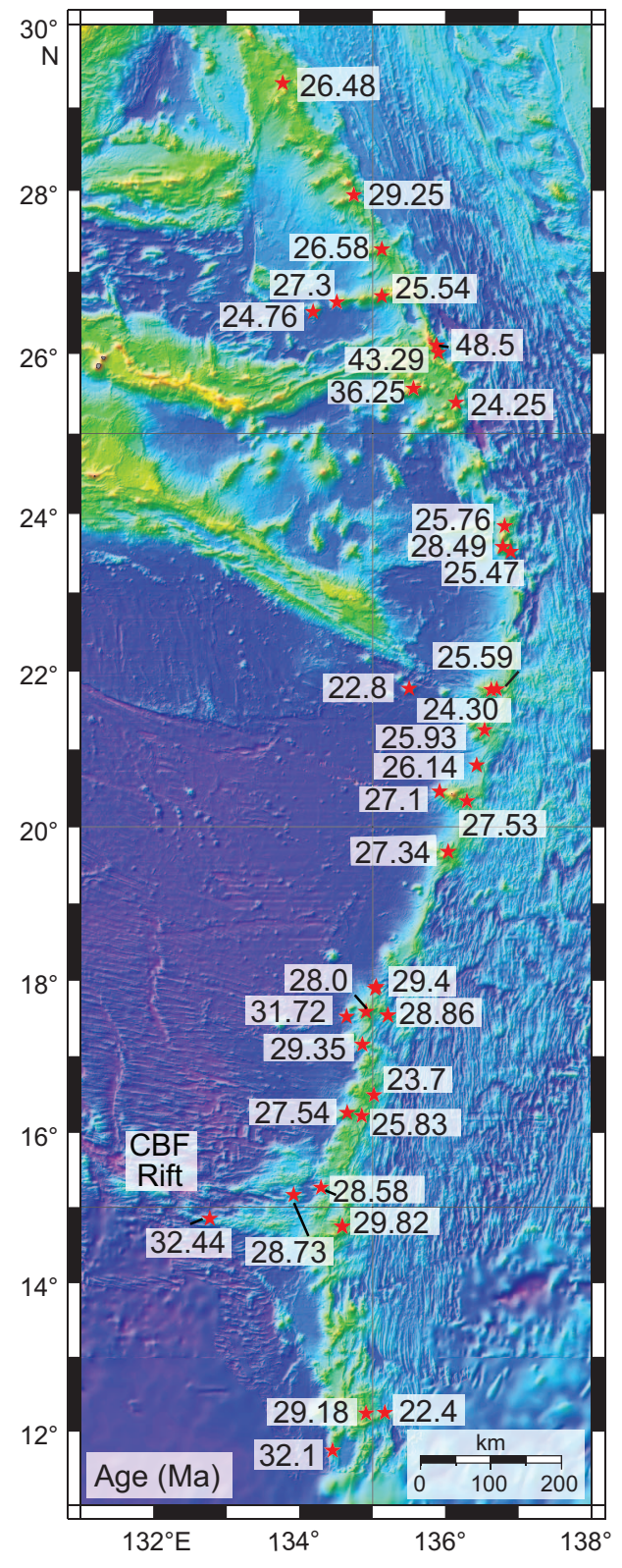

anomaly data and seafloor fabric observations. Okino et al. (1994) identify a magnetic lineation corresponding to Anomaly 7 in the westernmost (oldest) margin of the basin and suggest spreading started at $26 \mathrm{Ma}$.

The lack of systematic age variations of volcanic rock along the KPR indicates that rifting was initiated almost concurrently along the entire ridge between $30^{\circ} \mathrm{N}$ and $11^{\circ} \mathrm{N}$. By extension, this means that initiation of the Shikoku and Parece Vela Basins and isolation of the KPR as a remnant arc occurred at about the same time. Even though the KPR is a remnant part of the IBM arc, the geochemical characteristics of the KPR magmatic lithologies are distinct compared to those of Quaternary age at the IBM arc volcanic front. Whereas the Quaternary IBM arc has clear along-arc geochemical variations (e.g., more enriched isotopic and trace element signatures) (Figure F6) both toward Honshu and the "alkalic volcano province," typified by the Iwo-To Volcano at the Izu-Bonin/Mariana intersection in the volcanic front and the rear arc (Bloomer et al., 
Figure F6. Variation of ${ }^{206} \mathrm{~Pb} / 204 \mathrm{~Pb}$ along-strike of volcanic rocks of the IzuBonin-Mariana arc and Kyushu-Palau Ridge (modified from Ishizuka et al., 2007, 2011b).
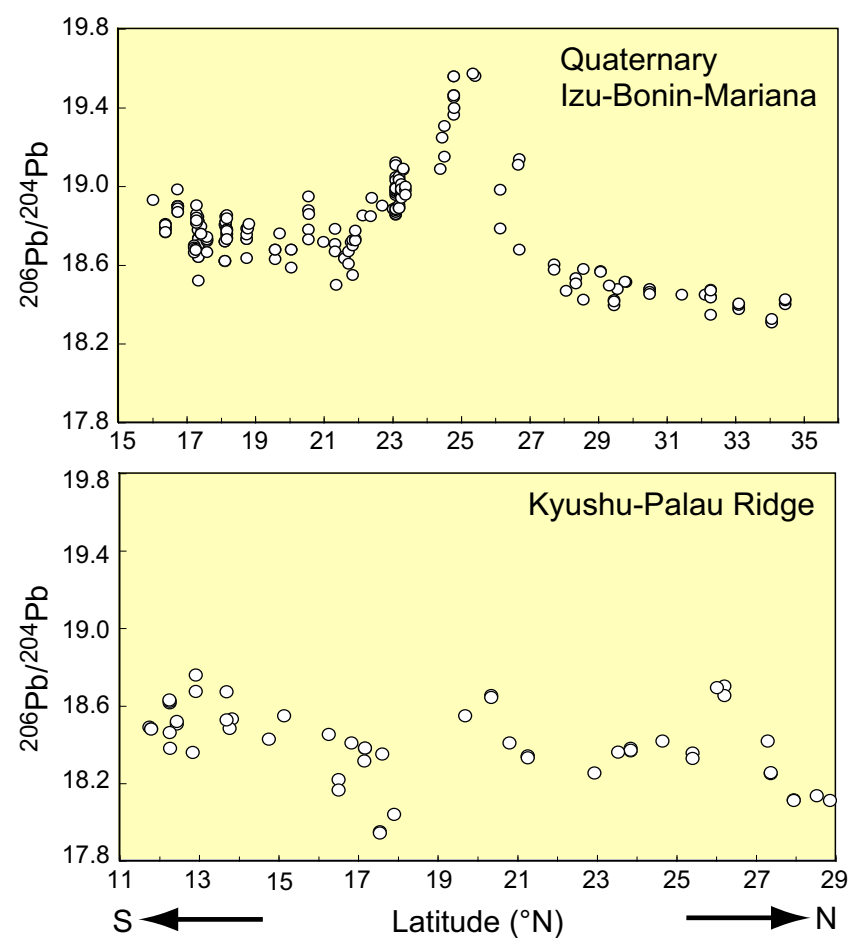

1989; Ishizuka et al., 2003, 2006b, 2007), the KPR does not show analogous systematic along-arc variations (Ishizuka et al., 2011b). This observation suggests the magmatic record obtained at Site U1438 is representative of adjacent along-strike KPR arc magmatism and provides us with representative magmatic evolution of the Paleogene stage of the IBM system.

However, there are locations where distinct geochemical signatures have been obtained along the KPR. One of these is where the Daito Ridge intersects the KPR. High-K andesite of Eocene age occurs in this area. These Eocene volcanic rocks from the KPR/Daito Ridge intersection have a distinctly enriched trace element and isotopic character relative to the surrounding KPR samples. In particular, they have higher ${ }^{206} \mathrm{~Pb} /{ }^{204} \mathrm{~Pb}$ and elevated light versus heavy rare earth element ratios in combination with small deviations of ${ }^{208} \mathrm{~Pb} /{ }^{204} \mathrm{~Pb}$ from the Northern Hemisphere Reference Line (i.e., $\Delta^{208} \mathrm{~Pb} / 204 \mathrm{~Pb}$ ) relative to the KPR (Figure F7). Arc magmatism at the $\mathrm{KPR} /$ Daito Ridge intersection is thought to have been established on crust of the preexisting Daito Ridge, which is a Mesozoic remnant arc. Therefore, it is possible the distinct geochemical characteristics of the KPR/Daito Ridge intersection are related to the involvement of sub-Daito Ridge lithospheric mantle or subarc crust, which was metasomatized by a Cretaceous-aged subduction event. This critically important hypothesis can be tested through the geochemical character of the arc basement, part of which was drilled during Expedition 351 at Site U1438. Similarly, such geochemical variations in KPR volcanic products will facilitate determination of the provenance of Site U1438 volcaniclastic sediments.

\section{Amami Sankaku Basin}

The initial products of the IBM system are preserved today in two longitudinal belts: (1) one forming the eastern margin of the WPB and abandoned as a remnant arc (the KPR) and its basement
(ASB) (Figure F2) when the Parece Vela-Shikoku Basin opened; and (2) a second belt preserved in the IBM fore arc that is mostly submarine but emerges sporadically as islands, such as Chichijima and Guam. The ASB is bordered to the west across a major northsouth-striking fault scarp (Minami-Amami Escarpment [MAE]) by the Amami Plateau, to the south by the Daito Ridge group, and to the northeast by the KPR. It is important to note the KPR is not oriented parallel to either the Amami Plateau-Daito Ridge or the MAE. Instead, the strike of the KPR is at a high angle to the trends of these features, apparently constructed independently of any preexisting basement fabric. If the MAE represents a fossil transform fault adjacent to an ASB basement formed through seafloor spreading, it appears the initiation of the KPR was independent of preexisting transform fault control, inconsistent with the majority of models that have been proposed for subduction inception for this arc system.

The eastern part of the Daito Ridge south of the ASB has a ${ }^{40} \mathrm{Ar} /{ }^{39} \mathrm{Ar}$ date of $118 \mathrm{Ma}$ (Ishizuka et al., 2011b). Prior to Expedition 351, it appeared possible that the early ASB sediment and basement might be Early Cretaceous or older (i.e., Neotethyan). The Seton et al. (2012) plate reconstruction estimates Pacific plate basement with an age ranging from $\sim 100 \mathrm{Ma}$ in the vicinity of the ASB to $\sim 140 \mathrm{Ma}$ in the southern Marianas. Recovery of the ASB basement allows us to determine whether this is a captured remnant of the Pacific plate.

Reconnaissance of the subseafloor crust along the western margin of the ASB was begun on a Shinkai 6500 dive $(337 ; 1996)$ conducted at the MAE (Fujioka et al., 1997) (Figure F8). The dive started at the foot of a $1 \mathrm{~km}$ high steep cliff and ascended to the top of the escarpment. Lithologies identified on the dive transect from shallower to deeper parts along the submersible track line were ash turbidite with burrows, altered tuffs, calcareous chalk (sic), scoria, and basalt breccia with calcareous matrixes, all covered with pelagic mud and manganese-bearing sediments. Occasional pumice blocks were scattered on the sediment surface. Intact basaltic basement (pillows or sheet flows) was not observed. Sediment samples obtained during this dive were predominantly pelagic brown mud, indicating deposition below the carbonate compensation depth (CCD). However, calcareous chalk is consistent with a shallower depositional environment for the older lithologies. The topography of the escarpment is a combination of gentler sedimented slopes with steep to occasional overhanging cliffs. A notable slump scar, erosional gulley, and slope failure-induced debris flows and turbidites were seen everywhere along the dive track. These phenomena strongly suggest the occurrence of past slope failure in relation to likely fault movement along the MAE.

\section{Seismic studies/site survey data}

The Japan Oil, Gas, and Metals National Corporation (JOGMEC) acquired extensive multichannel seismic (MCS) reflection data in the northern part of the PSP (Higuchi et al., 2007). These surveys covered a wide area of the IBM-KPR, as well as the Amami Plateau and Daito Ridge regions; the major objective of the surveys was to obtain detailed images of the sedimentary and deeper crustal structures. These data provide important information for drilling into the sedimentary and igneous sections, particularly in the ASB (Figure F9). The interpretation of these profiles (Figure F10) coupled with information from DSDP holes (e.g., 296, 445, and 448) and Ocean Drilling Program (ODP) Site 1201 (see Figure F2 for relation to Site U1438), have resulted in the description of two major layers in the ASB, the igneous basement and overlying sedimentary section (Figure F10). On the basis of comparison of 
Figure F7. Distinct geochemical characteristics of volcanic rocks from the Kyushu-Palau Ridge (KPR)/Daito Ridge intersection (modified from Ishizuka et al., $2011 \mathrm{~b}$ ). $\mathrm{Pb}$ isotopes clearly discriminate these volcanic rocks from other KPR volcanics. $\Delta 8 / 4=$ deviation of ${ }^{208} \mathrm{~Pb} / 2{ }^{204} \mathrm{~Pb}$ at a specific ${ }^{206} \mathrm{~Pb} /{ }^{204} \mathrm{~Pb}$ compared with the Northern Hemisphere reference line. EM-1, enriched mantle 1, EM-2 = enriched mantle 2, MORB = mid-ocean-ridge basalt, PSP = Philippine Sea plate, OIB = ocean-island basalt, $\mathrm{HIMU}=$ high $\mu\left({ }^{238} \mathrm{U} /{ }^{204} \mathrm{~Pb}\right)$.

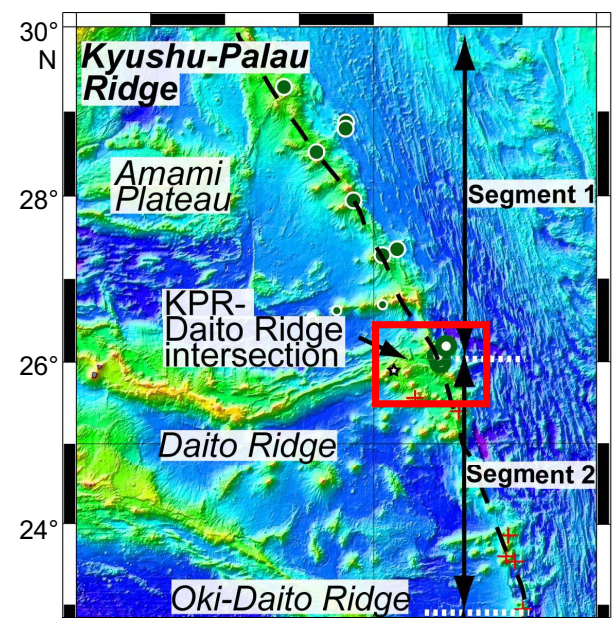

Figure F8. Location of Shinkai 6500 Dive 337 and Site U1438.

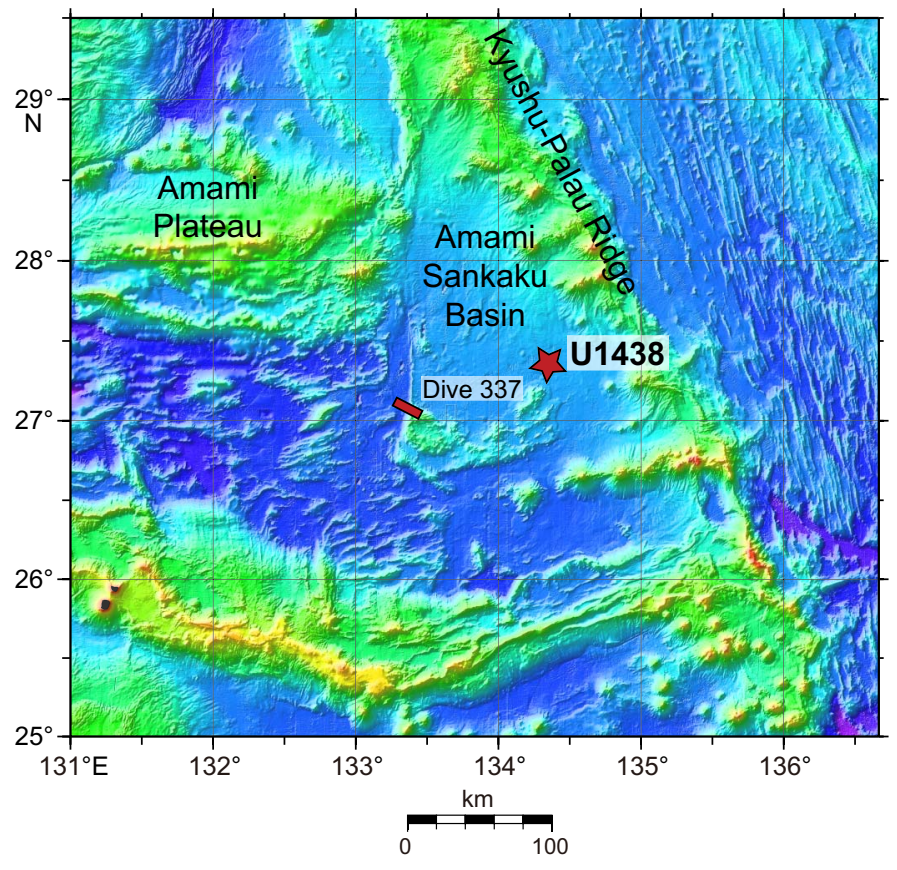

MCS reflection profiles in the northwestern Philippine Sea, including some that traverse the ASB, Higuchi et al. (2007) suggest the oldest sediments in the ASB are late to middle Eocene in age.

According to Higuchi et al. (2007), the sediments of this region of the ASB contain five stratigraphic units. The top unit $(\sim 110 \mathrm{~m}$ thick) is estimated to comprise Pliocene-Pleistocene pelagic sediment. The second unit ( $160 \mathrm{~m}$ thick) is suggested to be upper Miocene turbidites, which may have come from the KPR but are proposed to be more likely pelagite given the termination of eruptive activity on the KPR by this time. The third unit ( 310 m thick) is suggested to be lower Miocene turbidites derived from the magmatically extinct KPR. The fourth unit (490 m thick) is estimated to

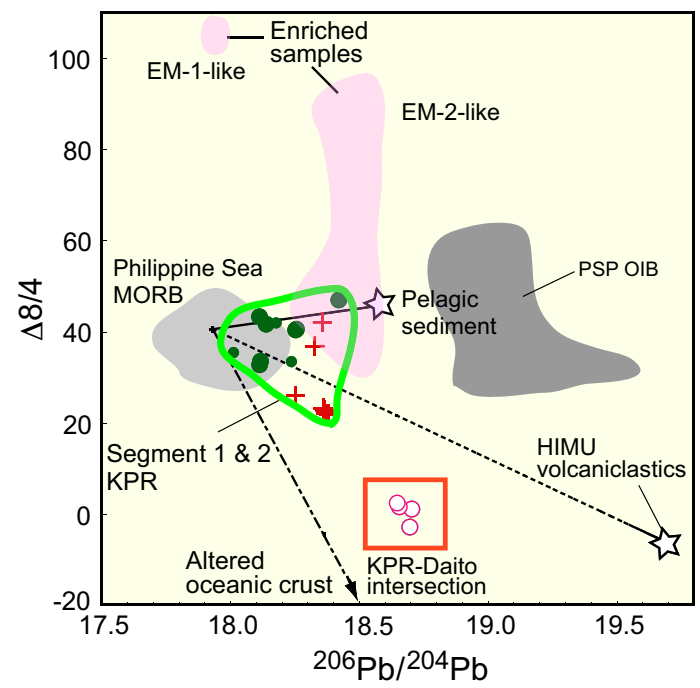

be Oligocene and Eocene volcaniclastic turbidites from the KPR. The thickness of this unit increases eastward toward the KPR with a maximum exceeding $1 \mathrm{~km}$, which is consistent with a predominant source on the ridge. The final sedimentary unit ( $230 \mathrm{~m}$ thick) is suggested to be pelagic sediment of Eocene or older age; the distribution of this layer is discontinuous across the ASB but present at Site U1438.

Site U1438 was selected at the intersection of two MCS profiles (Lines D98-A and D98-8) obtained by JOGMEC (Figures F9, F10) located $\sim 50-80 \mathrm{~km}$ southwest of the nearest part of the KPR.

It is also useful to examine the seismic and lithologic structures of another drilled site in the WPB because of the shedding of pyroclastic debris and ash from the KPR at Site U1438. One of the objectives of ODP Leg 195 was coring and casing a hole (Site 1201) in the WPB (Figures F2, F11) for the installation of a broadband seismometer as part of the International Ocean Network of seismometers (Shipboard Scientific Party, 2002). Site 1201 lies $100 \mathrm{~km}$ west of the KPR on putative 49 Ma crust (near Chron 21) formed at the CBF Rift (Figure F5; extinct spreading center) of the WPB. Based on this age, the basement at Site 1201 formed just after IBM arc initiation and so cannot be used to satisfy the specific objectives for Expedition 351. Nevertheless, some aspects of the sedimentological processes at the former location are contextually important. As Site 1201 drifted away from the CBF Rift spreading center, volcanism ceased and about $0.5 \mathrm{~km}$ of sediment was deposited in three stages: (1) quiescent marine sedimentation in deep water into the late Eocene; (2) pelagic sedimentation mixed with, and finally overwhelmed by, volcaniclastic turbidites from the KPR from the late Eocene through the early Oligocene; and (3) waning turbidite deposition, followed by deep-sea pelagic sedimentation below the CCD from the early Oligocene to the early Pliocene, when sedimentation ceased altogether, as reported by Salisbury et al. (2006).

Subsequent to ODP drilling at Site 1201, a new MCS line (D992) (Figure F11) was run northwest-southeast through the site and across the KPR into the Parece Vela Basin. One feature of this seismic line is the thickening of the upper part of the sedimentary package toward the prominent topographic high of the KPR and the relative constancy in thickness of the lower parts. 
Figure F9. Track map of MCS survey Lines D98-A and D98-8. Site U1438 is located at the intersection of the two survey tracks (modified from Japan National Oil Corporation, 1998).

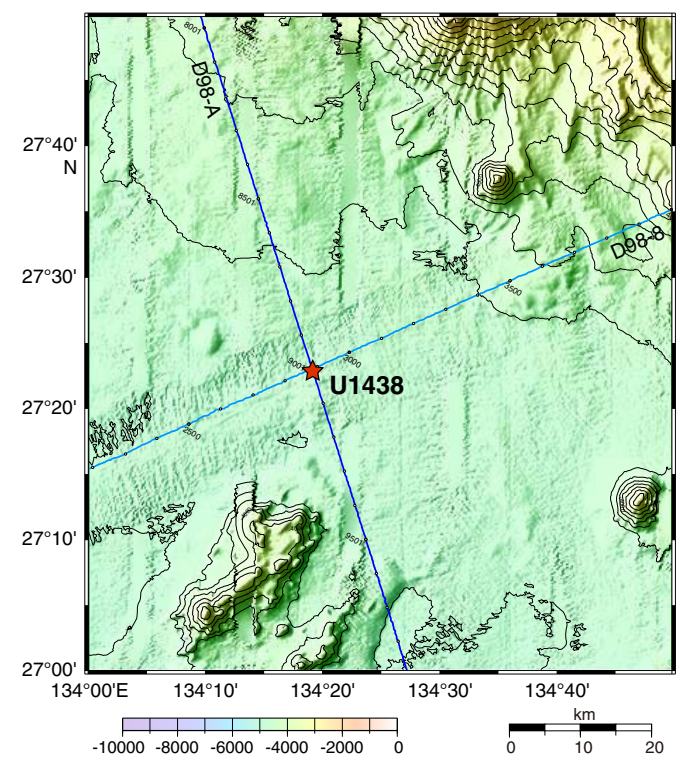

Figure F10. Seismic reflection images, Site U1438 (modified from Japan National Oil Corporation, 1998). Top two panels show MCS Line D98-8 (upper) and interpreted major reflectors (lower) with the location of Site U1438. Lower two panels show MCS Line D98-A (upper) and interpreted major reflectors with the location of Site U1438 (lower). Seismic interpretation from Higuchi et al. (2007).
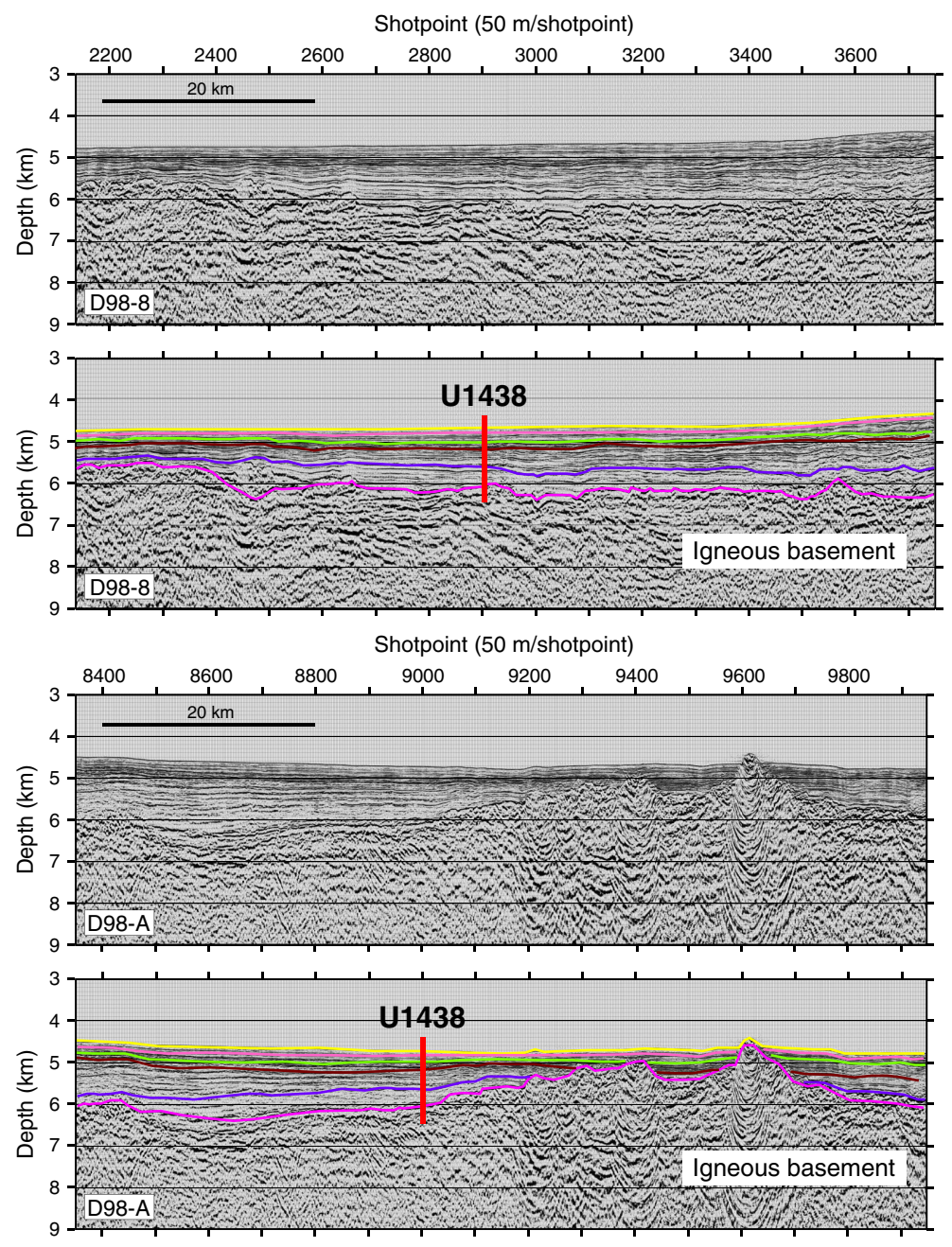
Figure F11. Location of MCS Line D99-2 and ODP Site 1201 (right) and results from the same line in cross-section (left).

NW

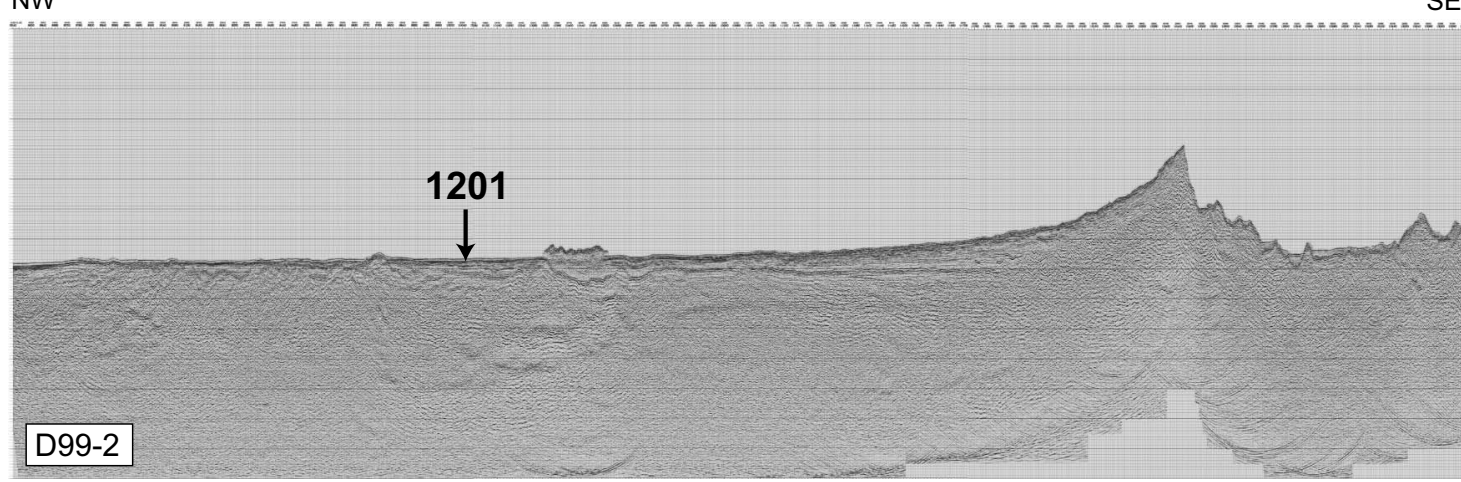

SE

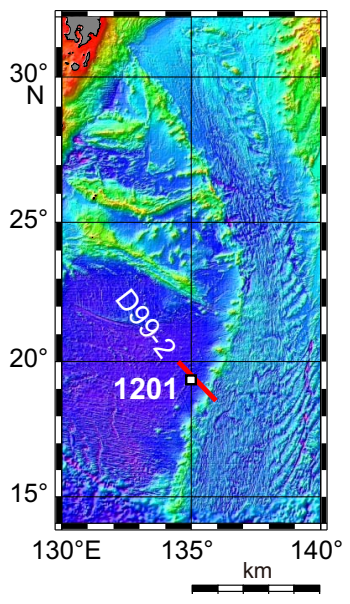

\section{Scientific objectives}

Understanding how subduction zones are initiated and continental crust forms in intraoceanic arcs requires knowledge of the inception and evolution of a representative intraoceanic arc, such as the IBM system. A nominally intraoceanic setting is preferable to avoid the obscuring geochemical, geophysical, and structural veils of preexisting continental crust, as well as the practicality of depth of recovery of basement sections by drilling. The IBM satisfies these criteria. Understanding the evolution of the IBM system, particularly in the more recent half of its $\sim 50$ My history, has improved considerably over the past three decades, not the least from studies of ash and other pyroclastic materials recovered by ocean drilling. However, we have poorer records for the nature of arc development in the first half of the history of the system and very limited understanding of how this (or any other) arc was initiated. Expedition 351 targeted, in particular, evidence for the earliest evolution of the IBM system following inception.

Expedition 351 is complementary to, yet distinct from, IODP Expeditions 350 and 352. Expedition 350 examined the history of rear-arc volcanism adjacent to the currently active volcanic front of the IBM arc, whereas Expedition 352 explored the sedimentary and igneous history preserved in the current IBM fore arc, potentially spanning the entire history of the system from inception onward. To some extent, the recovery objectives of the magmatic history of the arc during all these expeditions directly overlap but will also gain the vitally important perspective of across-strike recovery and identification of compositional variability of eruptive and potentially intrusive magmatic products.

In detail, Expedition 351 had several primary and secondary objectives involving both sediment and igneous basement.

\section{Primary objectives}

\section{Determine the nature of the original crust and mantle that ex- isted in the region prior to the beginning of subduction in the middle Eocene}

An essential boundary condition for understanding the evolution of island arcs is to know the composition, structure, and age of the crust and mantle that existed before subduction began. For example, unlike the case for calculations of the crust formation rate at mid-ocean ridges, estimates of intraoceanic arc fluxes commonly subtract a "standard" $7 \mathrm{~km}$ thickness of oceanic crust within the to- tal arc thickness as a probable pre-arc constituent (Reymer and Schubert, 1984; Fliedner and Klemperer, 2000). In addition, the simple assumption is made that the igneous ocean basement is equivalent to normal MORB, despite the evidence for significant variability both compositionally and structurally worldwide (Cannat et al., 2006; Gale et al., 2013). Depending on the mode of arc growth, preexisting nonarc crustal components should contribute geochemically through assimilation and partial melting processes triggered during the passage of later arc magmas and could make up an important part of the lower arc crust. We know that contamination-assimilation processes are commonly established during development of arc magmas, typically only clearly recognizable when strong geochemical contrasts exist between potential contaminantassimilant and the original magma (Arculus et al., 1983). In general, the presence of basement crust is assumed because recovery of samples from submature arc depths of $15-20 \mathrm{~km}$ is impossible. In the case of the proto-IBM system, we had an opportunity to define the geochemical nature of the preexisting basement; absolute trace element abundances together with ratios of these and various isotopic indicators of the basement rocks can then be utilized to quantify models of interaction between ascending IBM arc magmas and the basement.

In the northern IBM case, the preexisting oceanic crust exists under $1-1.5 \mathrm{~km}$ of sediment in the ASB adjacent to the KPR remnant arc and perhaps also crops out on the lower fore-arc slope of the Bonin Trench (DeBari et al., 1999; Ishizuka et al., 2011a). This crust makes possible access to samples of the pre-arc oceanic crustal basement upon which the arc was constructed. We know the age of IBM inception is $\sim 52-50 \mathrm{Ma}$ (Cosca et al., 1998; Ishizuka et al., 2011a). The ages of initial lithosphere foundering and the change to downdip subduction are consistent with geochronology of the change in strike of the edifices forming the Hawaiian-Emperor Seamount Chain, presumably recording the change in Pacific plate motion (Sharp and Clague, 2006; Whittaker et al., 2007). Recently published geochronology suggests that the bend in the seamount chain started at $\sim 50 \mathrm{Ma}$ and occurred over a period of $\sim 8 \mathrm{My}$ (Sharp and Clague, 2006).

All of the back-arc basins of the PSP are underlain by asthenosphere of Indian Ocean character, geochemically distinct from mantle sources beneath the Pacific plate now being subducted along its eastern margin (Hickey-Vargas, 1998b). In terms of a variety of radiogenic isotopic characteristics (e.g., $\mathrm{Pb}-\mathrm{Sr}-\mathrm{Nd}-\mathrm{Hf}$ ), Pacific and Indian Ocean MORB and OIB are distinct (Hofmann, 1997). Their 
mantle sources, as a consequence, must have contrasting geochemical compositions, at least in terms of the ratios of parent/daughter pairs of isotopic systems. Although the origins and development of these characteristics are controversial (e.g., Mahoney et al., 1998, and references therein), it appears breakup and dispersal of the Gondwanan continental lithospheric fragments during the Paleozoic and from then to the present have exposed asthenospheric mantle beneath the Indian Ocean that has been significantly modified geochemically compared with that of the sub-Pacific mantle. Juxtaposition of the Indian and Pacific MORB-source mantle types across a single one of a dense network of anomalously deep transform faults at the Australian-Antarctic Discordance (AAD) was explored, for example, during ODP Leg 187 (Kempton et al., 2002). The extent of Indian-type mantle migration eastward into the Pacific domain is not fully constrained, but the present locus of the IBM and former Vitiaz arc systems appear to mark a present-day limit. Possibly, the initiation of these arcs was in some way controlled by the juxtaposition of Pacific- and Indian-type mantles along the now-subducted Izanagi-Pacific Ridge (e.g., localized by the type of transform fault cluster exposed at the AAD).

It is nevertheless clear the initial construction of the IBM arc, rather than developing solely upon oceanic crust, transected the present-day series of Cretaceous-Paleocene ridges (e.g., Amami Plateau and Daito and Oki-Daito Ridges) and intervening basins that formed, at least in part, an arc-back-arc system (Taylor and Goodliffe, 2004; Hickey-Vargas, 2005; Ishizuka et al., 2011b) (Figure F2). Recent isotopic results for the Amami Plateau indicate the PSP also contains Pacific Ocean-type lithosphere, and the nature of the lithosphere on which the proto-IBM arc was built was likely diverse in character (Hickey-Vargas et al., 2008). Decoding the nature of the magma source in the upper mantle that existed immediately before the IBM arc inception is key to understanding the cause of the initiation of subduction zones and intraoceanic arc formation. It is also possible the basement of the ASB is of back-arc character, generated from upper mantle that was contaminated by Cretaceous subduction processes.

\section{Identify and model the process of subduction initiation and ini- tial arc crust formation}

According to the model of forced subduction initiation, the nucleating margin will first undergo compression and localized uplift; the Macquarie Ridge-Puysegur-Fiordland complex south of New Zealand is a present-day example (Figure F1) (House et al., 2002). Some segments of the margin may be forced above sea level (such as at Macquarie Island). Models show that the magnitude and horizontal wavelength of uplift are dependent on the age of the overriding plate, and knowledge of this age (see Primary Objective 1 basement and ages of deepest sediment overlying the basement at Site U1438, this objective) is an important geodynamic input (Gurnis et al., 2004). The self-nucleating model does not predict such a phase of uplift but predicts early extension. Understanding the response of the overriding plate during the initial stages in formation of the new subduction zone is thus essential for testing first-order competing proposals for subduction initiation.

The sedimentary sequence developed during subduction initiation recovered from the ASB at Site U1438 is crucial with respect to understanding the tectonic, petrologic, and geochemical consequences of the critical stages of arc inception. Depending on the wavelength of structural disturbance to the overriding plate, we anticipated erosion of crustal materials derived from the ridges and plateaus around the western and southern margins of the ASB. Suf- ficient geochemical and geochronological data have been collected (Ishizuka et al., 2011b, 2013; Tani et al., 2012) for these crustal sources that the materials shed into the ASB at this time will be recognizable in recovered cores at Site U1438. Similarly, uplift along the present trace of the KPR at the northeastern margin of the ASB may have reworked preinception sediment, and this together with juvenile arc-inception volcaniclastic materials will also be recognizable in cores. Any paleontological monitors of seafloor depth changes through subduction initiation and later periods of time will be critical for analyses of bathymetric changes to the ASB seafloor (e.g., changes in the CCD as well as the nature and preservation of benthic foraminifers).

The character of the earliest juvenile magmatic outputs of the nascent IBM arc recovered from the sedimentary sequence at Site U1438 is of first-order importance for (1) constraining the composition of the mantle wedge at this stage of arc development, (2) determining the nature of subducted inputs, and (3) comparing to the magmatic sequences recovered so far by drilling in the current fore arc (e.g., Reagan et al., 2010). An opportunity exists to explore possible across-strike variations in the nature of juvenile arc magmatic outputs and to establish the sequence recognized for the fore arc from earliest MORB-like FAB through boninite to the temporally more enduring and apparently stable output of island arc tholeiitic types, which also existed at the western margin of the earliest IBM arc.

In addition to chemical compositions and ages of fragmental materials deposited in the ASB concurrent with arc initiation, direct structural analysis of the cores will be a first-order requirement providing evidence for prevailing tension (normal faults), compression (thrust faults), or potentially tranquil tectonic environments. Evidence for temporal variations in these conditions are sought to model the state of stress in the overriding plate during arc initiation.

\section{Determine the compositional evolution during the Paleogene of the IBM arc}

The complete tephra record of fore-arc/arc/back-arc volcanism subsequent to arc initiation in the middle Eocene to the isolation of the KPR as a remnant arc accompanying inception of the Shikoku back arc basin at $\sim 25 \mathrm{Ma}$ (and possibly sporadically thereafter) is necessary from Site U1438. Comprehensive analytical data exist for Neogene ash and pyroclastic materials recovered from the IBM fore arc (e.g., Bryant et al., 1999; Straub, 2003; Straub et al., 2004) and indicate remarkable stability (a function of subducted slab inputs, mantle wedge replenishment, and overriding plate inputs) of the northern part of this system, but the Paleogene record is sparse. In combination with the known Eocene-recent lava/plutonic products (Ishizuka et al., 2011b), the ash and pyroclast record during this interval allows determination of the output variation through time along a transect of the northern IBM arc compared to Pacific plate inputs.

\section{Establish geophysical properties of the ASB}

The basement of the IBM arc comprises sedimentary and underlying igneous rock types that will become accessible for direct geophysical measurements through study of recovered cores and downhole logging at Site U1438. Following publication of the seminal seismic cross section obtained by Suyehiro et al. (1996), several other across- and along-strike seismic surveys have expanded our knowledge of the velocity structure of the IBM system (e.g., Kodaira et al., 2007). Wide-angle seismic refraction surveys have also documented the crustal thickness and structures of the Amami Plateau 
and the Daito and Oki-Daito Ridges (Nishizawa et al., 2014). Recovery and analysis of core samples, together with comprehensive downhole logging of physical-chemical-structural properties of the pre-arc basement and overlying sediments, will clearly advance our understanding of the overall nature of the KPR structure, permitting reliable estimates of age-composition characteristics of crustal units and enabling refined calculation of the critically important question of arc crustal growth rates.

There is a long-standing debate concerning the initial geographic orientation and locations of the IBM system during subduction initiation (argued to be $\sim 090^{\circ}$ ) and its subsequent postulated $90^{\circ}$ clockwise rotation to a present-day north-south strike during 50 My (Hall et al., 1995; Yamazaki et al., 2010, and references therein). Among the primary objectives of Expedition 351 was establishing the magnetic declination and any change as a function of time for both the ASB basement and overlying sediments. Although these measurements are technically challenging, a particular advantage is offered at Site U1438 in attempting magnetic orientation measurements because of the apparently relatively undisturbed sediment character. The initial orientation of the IBM system and any subsequent rotations are important with respect to establishing the boundary conditions for subduction initiation and later plate interactions.

\section{Secondary objectives}

\section{Recover sedimentary records of paleoceanographic conditions from the Pliocene-Pleistocene to early Tertiary in the western Pa- cific}

The paleographic position of the ASB adjacent to Cretaceousaged arcs and back-arc basins potentially provides an excellent opportunity to recover records of paleoceanographic conditions during the Tertiary.

\section{Recover sedimentary records of onset and persistence of the East Asian Monsoon and other climate-modulated land-sea correla- tions}

Integrated Ocean Drilling Program Expedition 346 recovered cores to the north of Site U1438 to test hypotheses concerning tectonic linkages with the onset of the Asian Monsoon. As Site U1438 is located southeast of the Expedition 346 sites, they may be complementary. Although our site is distal from the Yangtze River discharge, a record of fluvial input is possible. Furthermore, potential eolian inputs to the ASB include loess from eastern Asia. Thus, high-quality sediment recovered by advanced piston corer (APC) coring at Site U1438 should provide additional important information regarding timing and geographic distribution of terrestrial material in the western Pacific marine record.

\section{Recover an ash record of the evolution of the Ryukyu-Kyushu arc}

Subduction of the PSP, on which the ASB now is situated, takes place in part along the Ryukyu-Kyushu arc northwest of Site U1438 (Figure F2). We anticipate an ash record from this arc has been recovered within the sediment at this site. Some particularly significant explosive events from the Ryukyu-Kyushu arc produced extensive ash deposits that are used as stratigraphic marker horizons in the Japanese islands (Machida, 1999). In addition to this feature, the temporal evolution of the Ryukyu-Kyushu arc located on the east Asian continental margin will provide important complementary evidence of arc evolution with the IBM system.

\section{Principal science results Lithostratigraphy}

The lithostratigraphic record at Site U1438 is composed of sediments, sedimentary rocks, and igneous rocks recovered in Holes U1438A, U1438B, U1438D, and U1438E (Figure F12; Table T1). Sediments and sedimentary rocks at Site U1438 were sampled from the seafloor to 1461 meters below seafloor (mbsf) and are divided into four lithostratigraphic units. Unit I is $160.3 \mathrm{~m}$ thick and is Holocene to latest Oligocene in age (Pleistocene in Hole U1438A). Unit I sediments are primarily terrigenous, biogenic, and volcaniclastic mud and ooze with interspersed discrete ash layers. Unit II is 139.4 $\mathrm{m}$ thick and is Oligocene in age. Unit II sedimentary rocks are tuffaceous mudstone, siltstone, and fine sandstone, with localized slumping-induced deformation features. The mudstone to sandstone intervals are typically normally graded beds with sharp lower boundaries to the sandstone bases, as well as moderately to strongly bioturbated mudstone caps. Unit III is $1046.4 \mathrm{~m}$ thick and is Oligocene to Eocene in age. Unit III sedimentary rocks are on average coarser grained than those of Unit II (Figure F12) and include tuffaceous mudstone, tuffaceous sandstone, tuffaceous medium to coarse sandstone with gravel, and tuffaceous breccia-conglomerate with volcanic and sedimentary clasts commonly up to pebble and rarely cobble size. At the largest scale, Unit III comprises five intervals of coarser clastic sedimentary rocks, separated by intervening mudstone-dominant intervals lacking discrete breccia-conglomerate beds. Unit IV is $99.7 \mathrm{~m}$ thick and is Eocene in age. Unit IV is composed of radiolarian-bearing mudstone underlain by medium to coarse sandstone, breccia-conglomerate, and tuffaceous siltstone and mudstone. Unit IV is underlain at $1461 \mathrm{mbsf}$ by igneous basement rocks that comprise Unit 1 . Within Unit 1, several cooling contacts were recognized, but substantial drilling disturbance made consistent recognition of individual volcanic unit boundaries and estimation of thicknesses impractical, so all igneous basement rocks are grouped together in a single unit. Unit 1 is $150.0 \mathrm{~m}$ thick and is presumably Eocene in age. Unit 1 basalts are sparsely vesicular to nonvesicular and microcrystalline to fine grained. Most samples are aphyric, but some contain phenocrysts of plagioclase, clinopyroxene, and olivine up to $4 \mathrm{~mm}$ in their long dimension. Groundmass textures are variable from subophitic (holocrystalline) to intersertal (hyalophitic) and glassy. Macroscopic alteration of phenocrysts and groundmass to chlorite, oxides, and carbonate pervades rocks of Unit 1 , which are also cut by chlorite + carbonate \pm sulfide and oxide veins.

\section{Mineralogy and alteration}

Downhole changes in mineralogy at Site U1438 are documented from smear slide, X-ray diffraction (XRD), and thin section observations and show the dominantly fresh volcanogenic minerals and glass that occur within Unit II (shallower than $300 \mathrm{mbsf}$ ) are transformed into mixtures of dominantly clay and zeolite minerals in Unit III (deeper than 500 mbsf).

Plagioclase, pyroxene, and calcite are the dominant minerals in Unit II, with minor occurrences of amphibole, based on smear slide observations and XRD patterns. The identification of foraminifers and nannofossils in many smear slides from Unit II indicate that calcite occurs primarily as a sedimentary component. Smear slide observations indicate that the silicate minerals and associated volcanic glass in Unit II are largely free of hydrous alteration effects. 
Figure F12. Graphic summary of stratigraphy, Site U1438. Lith = lithologic, Cl = clay, Si = silt, Vfs-fs = very fine sand-fine sand; Ms-vcs = medium sand-very coarse sand, $\mathrm{Gr}=$ gravel. Sediment grain size is averaged over $5 \mathrm{~m}$ intervals.

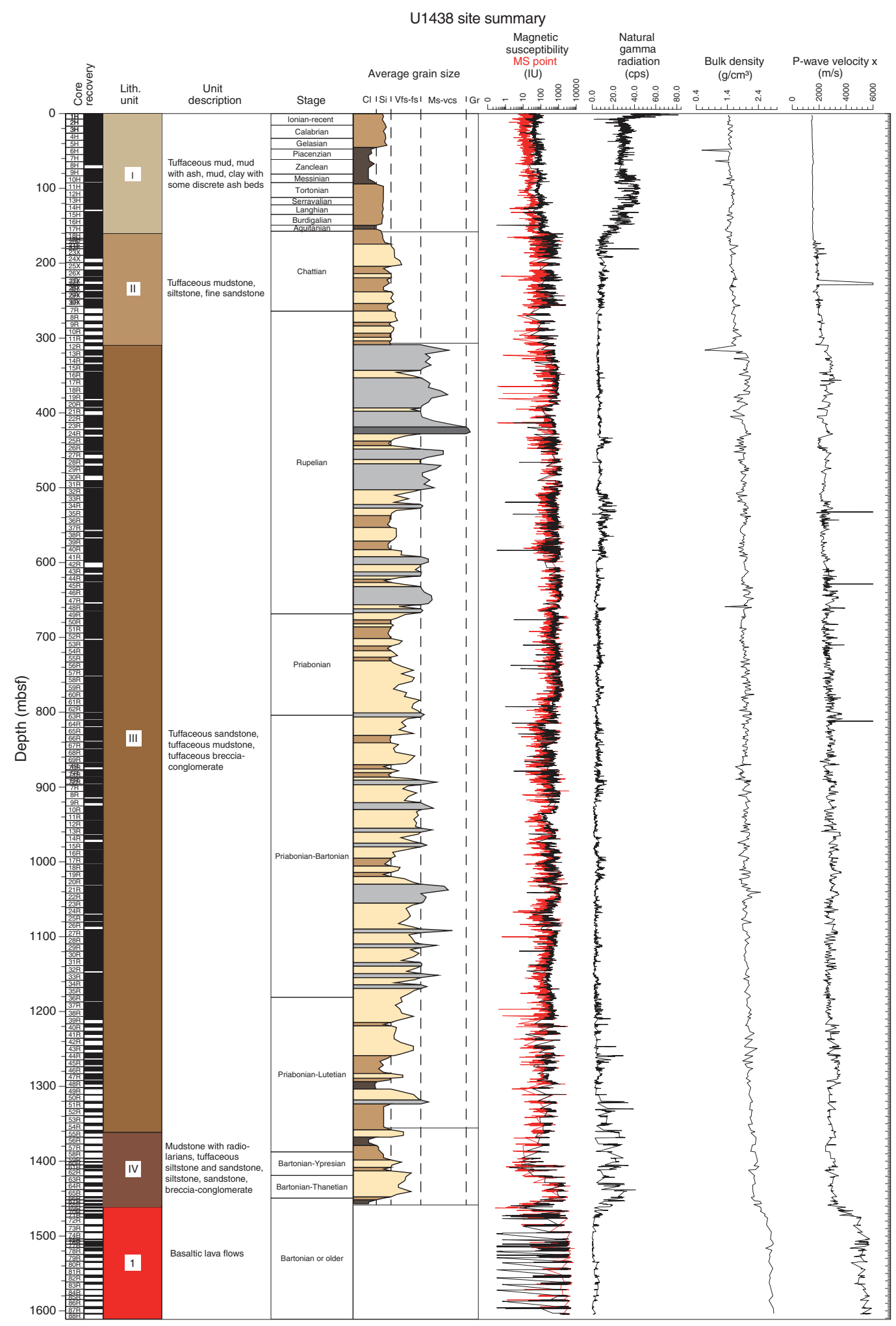

In the upper part of Unit III, at 300-500 mbsf, zeolite minerals observed in trace quantities in Unit II become common and their abundance increases relative to fresh, volcanogenic components. XRD data for Unit III show that calcic plagioclase and pyroxene are still abundant minerals, as they are in Unit II. Calcite is also com- monly present, as in Unit II, but thin section observations confirm the presence of some authigenic cement. Most Unit III samples at 300-500 mbsf also contain one or more zeolite group minerals in combination with sheet silicate and other minerals that appear to be diagenetic. 
Table T1. Expedition 351 operations summary. Download table in .csv format.

\begin{tabular}{|c|c|c|c|c|c|c|c|c|c|c|c|}
\hline Hole & Latitude & Longitude & $\begin{array}{l}\text { Water } \\
\text { depth } \\
\text { (mbsl) }\end{array}$ & $\begin{array}{l}\text { Cores } \\
(N)\end{array}$ & $\begin{array}{l}\text { Interval } \\
\text { cored } \\
(\mathrm{m})\end{array}$ & $\begin{array}{l}\text { Core } \\
\text { recovered } \\
(\mathrm{m})\end{array}$ & $\begin{array}{l}\text { Recovery } \\
(\%)\end{array}$ & $\begin{array}{l}\text { Drilled } \\
\text { interval } \\
(\mathrm{m})\end{array}$ & $\begin{array}{l}\text { Total } \\
\text { penetration } \\
\text { (m) }\end{array}$ & $\begin{array}{l}\text { Time } \\
\text { on hole } \\
\text { (days) }\end{array}$ & Comments \\
\hline U1438A & $27^{\circ} 23.0108^{\prime} \mathrm{N}$ & $134^{\circ} 19.1020^{\prime} \mathrm{E}$ & 4700.2 & 3 & 26.5 & 24.90 & 94 & - & 26.5 & 0.97 & $\begin{array}{l}\text { Limited shipboard analyses; high- } \\
\text { resolution personal sampling }\end{array}$ \\
\hline U1438B & $27^{\circ} 23.0111^{\prime} \mathrm{N}$ & $134^{\circ} 19.1087^{\prime} \mathrm{E}$ & 4700.5 & 30 & 257.3 & 227.04 & 88 & - & 257.3 & 1.64 & $\begin{array}{l}\text { APC cores (19); half-length APC } \\
\text { cores (3) }\end{array}$ \\
\hline U1438C & $27^{\circ} 22.9963^{\prime} \mathrm{N}$ & $134^{\circ} 19.0883^{\prime} \mathrm{E}$ & 4700.2 & - & - & - & - & 65.0 & 65.0 & 0.77 & Jet-in test \\
\hline U1438D & $27^{\circ} 23.0218^{\prime} \mathrm{N}$ & $134^{\circ} 19.1023^{\prime} \mathrm{E}$ & 4700.2 & 71 & 678.8 & 523.17 & 77 & 219.0 & 897.8 & 9.48 & $\begin{array}{l}\text { RCB pilot hole; FFF deployed; } \\
\text { logging ( 100-300 mbsf) with } \\
\text { triple combo }\end{array}$ \\
\hline U1438E & $27^{\circ} 23.0153^{\prime} \mathrm{N}$ & $134^{\circ} 19.0898^{\prime} \mathrm{E}$ & 4700.0 & 85 & 743.7 & 450.73 & 61 & 867.3 & 1611.0 & 32.49 & $\begin{array}{l}\text { Reentry hole; casing to } 605 \text { mbsf; } \\
\text { logging (600-1186 mbsf) with } \\
\text { triple combo, GBM }\end{array}$ \\
\hline \multirow[t]{2}{*}{ U1438F } & $27^{\circ} 23.0167^{\prime} \mathrm{N}$ & $134^{\circ} 19.0905^{\prime} \mathrm{E}$ & 4699.9 & - & - & - & - & 700.0 & 700.0 & 5.08 & $\begin{array}{l}\text { Dedicated wireline logging hole: } \\
\text { triple combo, FMS-sonic, VSI }\end{array}$ \\
\hline & & \multicolumn{2}{|c|}{ Site U1438 totals: } & 189 & 1706.3 & 1225.84 & & 1851.3 & & 50.43 & \\
\hline
\end{tabular}

Deeper than 500 mbsf in Unit III and to the bottom of Hole U1438D, many samples are dominated by zeolite and related framework and sheet silicate minerals, which are formed by diagenetic processes. In turn, the primary volcanogenic components, which dominate Unit II, diminish in importance in Unit III. Thin section and XRD data show that anhydrite may be present locally, where it appears together with zeolite minerals in replacement of pumice lapilli and in millimeter-scale veins. Calcite is less common in Unit III lithologies deeper than 500 mbsf but persists throughout most of Hole U1438D.

An additional style of diagenetic alteration is evident in Hole U1438D deeper than 600 mbsf, where a red to reddish brown stain has overprinted the dominantly grayish green, green, and black colors found in the diagenetically altered rocks from overlying Units II and III. It is likely that the red coloration reflects a change in the oxidation state of iron and the formation of trace amounts of hematite at the expense of magnetite in the fine-grained sediments.

Additional downhole changes in mineralogy are evident in the bottom third of Unit III, in the transition to Unit IV. These changes are most clearly expressed in the appearance of quartz in the XRD data for most Unit III samples deeper than 1120 mbsf, compared to shallower parts of Unit III, where quartz is rarely or only occasionally present. Other minerals that appear sporadically in lower Unit III and in Unit IV and are not present in the upper part of Unit III include K-feldspar, prehnite, serpentine, and hematite.

\section{Structural geology}

Structural features are limited to a few intervals within Site U1438 cores. Smaller scale features, such as faulted and dipping beds, are restricted to the middle part of Unit II, around the overlap zone between Holes U1438B and U1438D. The structures consist of moderately dipping $\left(40^{\circ}-65^{\circ}\right)$ planar structures of normal and reverse (thrust) geometry that offset the inclined bedding. The zone of deformation is 50-70 m wide, and correlation between Holes U1438B and U1438D suggests northwesterly dip at a moderate angle $\left(40^{\circ}-60^{\circ}\right)$ for this structural zone. A few inclined beds were noted at widely spaced locations in Unit III throughout Hole U1438D, but they probably resulted from localized slumping and loading. Toward the bottom of Hole U1438D, bedding orientation changes rapidly, suggesting chaotic small-scale folding, and small reverse offsets on moderately dipping bedding planes are ubiquitous.

\section{Biostratigraphy and micropaleontology}

A summary of the age-depth plot derived from biostratigraphy is depicted in Figure F13. Calcareous nannofossils generally range from medium to low abundance, although many samples are barren, particularly at the top and toward the bottom of Site U1438. Nannofossil marker species for Zones NP 25 through NP 19/NP 20 are present. The base of Zone NP $25(26.84 \mathrm{Ma})$ was assigned between 180.65 and 189.44 mbsf (Hole U1438B) based on the last occurrence (LO) of Sphenolithus distentus. Between 269.84 and $280.66 \mathrm{mbsf}$ (Hole U1438D), material was constrained to the base of Zone NP 24 (29.62 Ma) based on the first occurrence (FO) of Sphenolithus ciperoensis. The LO of Reticulofenestra umbilica, encountered between 548.7 and $555.71 \mathrm{mbsf}$, identifies the base of Zone NP 23 (32.02 Ma). Cores recovered between 565.7 and 576.79 mbsf were assigned to the base of Zone NP 22 (32.92 Ma) based on the LO of Coccolithus formosus. The base of Zone NP 21 (34.44 Ma) was identified between 729.58 and 733.07 mbsf based on the LO of Discoaster saipanensis. The interval 733.07-809.11 mbsf was assigned to Zone NP 19/NP 20 (34.44-36.97 Ma) based on the presence of D. saipanensis, Discoaster barbadiensis, and Isthmolithus recurvus. One final interval in Hole U1438E ( 1181 mbsf) was constrained to Zones NP 20-NP 17 (top) (34.44-38.25 Ma) based on the occurrences of D. saipanensis, D. barbadiensis, and Reticulofenestra bisecta. Deeper samples are barren of nannofossils.

Planktonic foraminifers are barren in the majority of samples, although many samples do contain age-diagnostic species and so are able to significantly contribute to the age model for Site U1438. Samples from 0 to $\sim 177$ mbsf (Hole U1438B) are largely barren, apart from several foraminifer oozes at $\sim 8,12.5,16$, and $27 \mathrm{mbsf}$. These contain rich assemblages of typical Pleistocene species, which include the age-diagnostic Globorotalia tosaensis, Globorotalia hessi, and Globorotalia inflata, constraining the samples to Zones PL4 through Pt1 (<3.6 Ma). The interval between 223 and $235.2 \mathrm{mbsf}$ is constrained to the base of Zone O6 (26.93 Ma) based on the presence of the species Paragloborotalia mayeri and Paragloborotalia opima. The interval at $\sim 483 \mathrm{mbsf}$ (Hole U1438D) is constrained to Zones O2 through E15 (30.28-36.18 Ma) based on the occurrence of Turborotalia ampliapertura, and the sample at $\sim 576$ mbsf is constrained to Zones O2 through E15 (30.28-32.1 Ma) based on the high abundance of T. ampliapertura. The only other age-diagnostic planktonic foraminifer was found at $\sim 1449 \mathrm{mbsf}$ 
Figure F13. Biostratigraphic- and paleomagnetic-based age-depth plot, Site U1438.

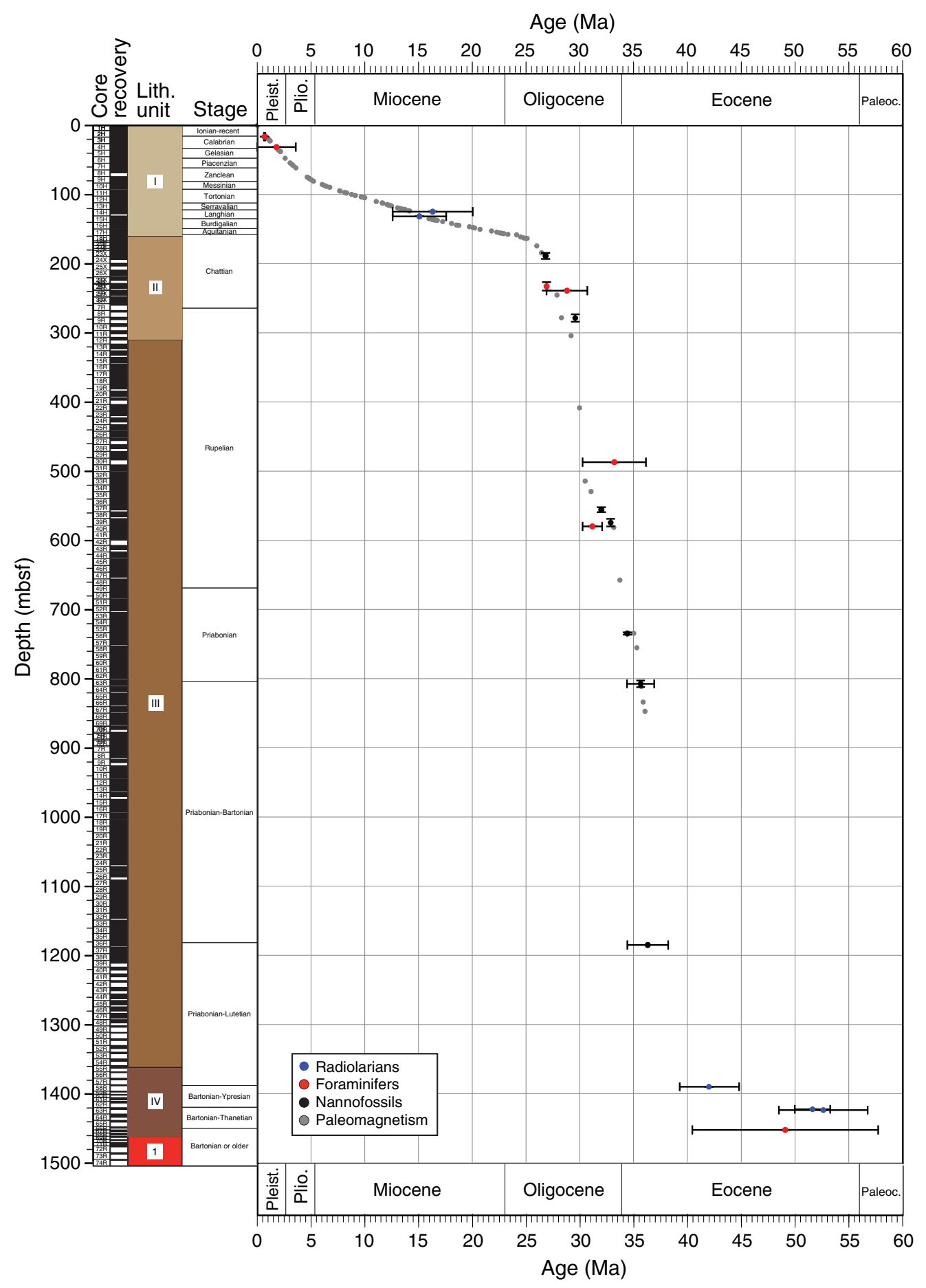

(Hole U1438E): a poorly preserved species of the genus Acarinina. It is likely to be either Acarinina soldadensis or Acarinina bullbrooki, which occur in Zones P4c through E11 (57.79-40.49 Ma).

Benthic foraminifers exhibit a similar occurrence pattern to planktonic foraminifers, but several intervals of moderate recovery allow the definition of four assemblage zones. Assemblage 1 (0-28 mbsf) ranges from $\sim 0$ to $1.6 \mathrm{Ma}$ and is characterized by a relatively high diversity of bathyal to abyssal benthics, including typical Neogene species Uvigerina peregrina, Cibicidoides mundulus, and Planulina weullerstorfi. These species occur only in the foraminifer ooze horizons, indicating that for the majority of this interval the site was below the CCD. The core top "mudline" sample contained agglutinated species including Rhizammina sp., Reophax sp., and Saccammina sp., confirming that Site U1438 (4700 m water depth) is below the CCD today. A barren interval follows, which passes into Assemblage 2 (166-245 mbsf; Hole U1438B), ranging from 25.5 to 29 Ma. It is characterized by sparse samples that include Cibicidoides spp., Nodosaria spp., Globocassidulina moluccensis, and Gyroidina sp. The species are typically found at lower bathyal to abyssal depths, and the generally low abundance and lack of many planktonic fora- 
minifers indicates the site may have been close to the CCD at this time. Assemblage 3 (257-430 mbsf; Hole U1438D) ranges from $\sim 29$ to $30.2 \mathrm{Ma}$ and is characterized by very low abundances of $\mathrm{Am}$ phistegina spp. and Lepidocyclina spp. These larger foraminifers, occurring exclusively in sandy intervals, were transported from the photic zone in shallow water. Assemblage 4 (520-587 mbsf) ranges from 31 to $33.2 \mathrm{Ma}$ and is characterized by low abundances of benthic species including bathyal to abyssal Cibicidoides havanensis and Stilostomella spp. One sample includes Sigmavirgulina tortuosa and Cibicidoides pachyderma that may be transported from neritic to upper bathyal depths. The interval 597-1460 mbsf is barren of benthic foraminifers.

In general, most of the samples recovered from Site U1438 are barren of radiolarians or only contain very low diversity and poorly preserved radiolarian assemblages. However, some samples yielded moderately preserved radiolarian faunas, which provide some biostratigraphic control in the Pleistocene-Holocene, early middle Miocene and latest Paleocene-middle Eocene. The interval 0-15.3 mbsf is constrained to Zones RN13-RN17 ( $<1.26 \mathrm{Ma}$ ) based on the presence of the species Lamprocyrtis nigriniae. The interval 121.3127.7 mbsf (Hole U1438B) is constrained to Zones RN2-RN5 (20.05-12.6 Ma) based on the presence of the species Stichocorys delmontensis. At about $127.8 \mathrm{mbsf}$, the radiolarian age is constrained to Zones RN4-RN5 (17.59-12.6 Ma) based on the presence of the species Calocycletta costata. At about $1387.6 \mathrm{mbsf}$ (Hole $\mathrm{U} 1438 \mathrm{E})$, the radiolarian age is constrained to Zones RP12-RP14 (46.21-40.65 Ma) based on the occurrence of Eusyringium fistuligerum, Lithocyclia ocellus, Periphaena tripyramis, Phormocyrtis striata striata, Sethochyrtis cf. triconiscus, Thyrsocyrtis rhizodon, and Thyrsocyrtis triacantha. Critically, at about $1419.7 \mathrm{mbsf}$, the radiolarian age is constrained to Zone RP8 (53.35-50.05 Ma) based on the occurrence of Buryella tetradica, Calocycloma castum, Lamptonium fabaeforme, Phormocyrtis cf. striata exquisita, Theocotyle cryptocephala, Theocotyle ficus, and Theocotyle nigrinae. In the last age-diagnostic sample ( $1420.3 \mathrm{mbsf})$, the radiolarian age is constrained to Zones RP7 (top) through RP9 (56.83-48.57 Ma) based on the occurrence of Buryella spp., Phormocyrtis spp., Podocyrtis spp., and Theocotylissa spp.

\section{Geochemistry}

For Site U1438, a total of 67 interstitial water (IW) samples for $\mathrm{pH}$ and chemical analyses, 160 headspace samples for hydrocarbon gas analyses, 111 samples for total carbon/total nitrogen and carbonate analysis, and 70 samples for bulk chemical analysis of the solid phase were taken. These samples were collected in Holes U1438A, U1438B, U1438D, and U1438E and span lithostratigraphic Units I, II, III, IV, and 1. Methane concentrations were low in all headspace samples, with an average of $2.35 \mathrm{ppm}$. Total organic carbon and total nitrogen concentrations were low $(<0.52$ and $<0.06$ wt\%, respectively) through all the cores. Carbonate content was generally low in Unit I except for a few intervals containing foraminiferal oozes, higher but variable in Unit II, and very low in Units III and IV except in a few intervals.

At Site U1438, IW chemical analyses indicate a $\mathrm{pH}$ increase downhole to a maximum of 9.9 and a decrease in alkalinity to a minimum of $0.6 \mathrm{mM}$. The depletion of ammonium and phosphate deeper than 250 mbsf (bottom of Hole U1438B) may be related to a sharp downhole decline of microbial activity. The downhole increase of salinity is related to the increase of $\mathrm{Ca}$ and $\mathrm{Cl}$ concentrations. $\mathrm{Mg}$ concentrations show an opposite trend with respect to $\mathrm{Ca}$, suggesting an exchange occurs between $\mathrm{Mg}$ and $\mathrm{Ca}$ during al- teration of volcaniclastic sediments. Aqueous concentrations of $\mathrm{K}$ and $\mathrm{Na}$ also decrease with depth, balancing the gain in $\mathrm{Ca}$ (Figure F14). This has been well documented in volcaniclastic settings in

Figure F14. Ca, Na, K, and Mg (note the twin scale used on the $x$-axis) in IW. $\mathrm{Ca}$ concentrations increase by $\sim 27$ times seawater value whereas $\mathrm{Na}, \mathrm{K}$, and $\mathrm{Mg}$ decrease. These chemical variations are best explained by breakdown of volcaniclastic sediment releasing Ca into IW followed by ion exchange reactions involving $\mathrm{Na}, \mathrm{K}$, and $\mathrm{Mg}$ during production of alteration phases downhole.

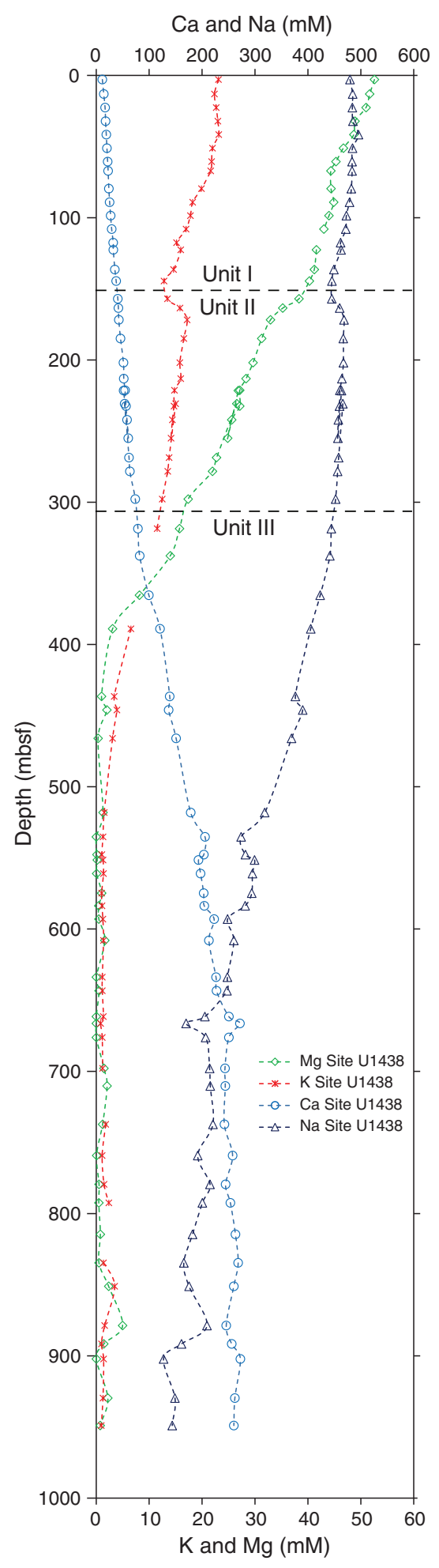


Western Pacific marginal basins and is observed in the Izu-Bonin fore arc at Sites 792 and 793, as well as the West Philippine Sea Basin, including Site 1201. Ba concentrations increase downhole, similarly to $\mathrm{Ca}$, again indicating the alteration of volcaniclastic sediments. An additional source is probably the basement, which could release these cations into the IW. The correlation between $\mathrm{Li} / \mathrm{B}$ and $\mathrm{pH}$ suggest that these elements may be released in the upper sediment, where $\mathrm{pH}$ is lower, as a result of silicate dissolution and desorption from clay minerals, but are retained in secondary minerals downhole where $\mathrm{pH}$ increases.

The downhole increase of Sr concentration in IW across Units I and II is most likely the result of low-temperature alteration of volcaniclastic sediments and the recrystallization of calcium carbonate. $\mathrm{Cl}$ and $\mathrm{Br}$ concentrations are nearly constant in Unit $\mathrm{I}$ and increase with depth in Units II and III, possibly due to a low-permeability layer at the Unit I/II boundary, which acts as a semipermeable "membrane," as well as mineral hydration processes at greater depth.

Bulk analysis of sediments shows loss on ignition (LOI) ranging from $3.91 \%$ to $14.47 \%$. The highest LOI values are from unconsolidated sediments in Unit II. In Unit III, CaO decreases in the sediments from $9.17 \mathrm{wt} \%$ ( 466 mbsf) to $3.04 \mathrm{wt} \%$ ( 1260 mbsf) and is inversely correlated with the increase of $\mathrm{Ca}$ in the IW. The silica content of the volcaniclastic-dominated sediments is extensive, ranging from levels equivalent to basalt to dacite, but with a majority of bulk compositions in the basaltic andesite to andesite composition (Figure F15). The $\mathrm{Si} / \mathrm{Mg}$ maximum, observed near conglomerate layers, suggests that during these time intervals the source of volcaniclastic debris was rhyolitic in composition.

Thirty-seven samples from the lava flows of Unit 1 were collected between Cores 351-U1438E-70R and 88R and analyzed for major and trace elements by inductively coupled plasma-atomic emission spectroscopy (ICP-AES) (Figure F16). The majority of these samples are high-MgO (mostly $>8 \mathrm{wt} \%$ ), low- $\mathrm{TiO}_{2}(0.6-1.1$ wt\%) tholeiitic basalts (Figure F15). Two sills sampled in Unit IV above the basement are $\mathrm{Na}$-rich basaltic andesite in composition.

\section{Paleomagnetism}

Paleomagnetic analyses of the sedimentary succession and underlying igneous rocks from Site U1438 have provided a continuous

Figure $\mathrm{F} 15 . \mathrm{MgO}$ vs. $\mathrm{SiO}_{2}$ for unconsolidated sediments and sedimentary rocks (Units I to III) and basalts from Unit 1.

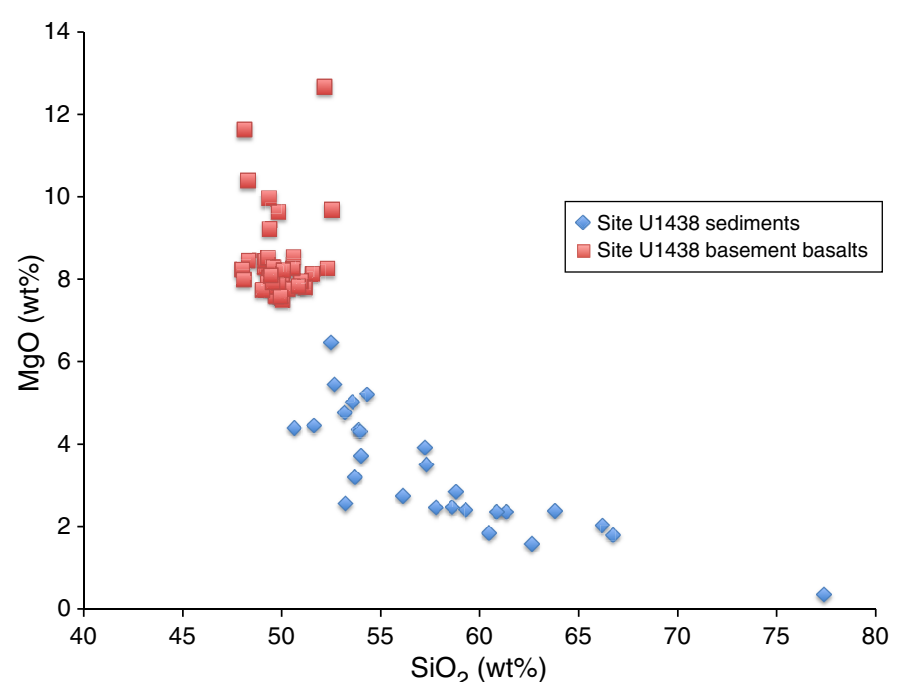

record of the geomagnetic field inclination for the last $~ 50 \mathrm{My}$. A total of 87 geomagnetic reversals have been recognized in the studied succession based on the inclination of the paleomagnetic vectors. This allowed precise dating of the cores to $847 \mathrm{mbsf}$, extending back to $36 \mathrm{Ma}$ (Figure F13). Deeper in Hole U1438E, higher magnetic coercivities of some intervals and more extensive overprinting by drilling-induced magnetic components in others prevented reliable identification of geomagnetic reversals, and no ages could be determined based on the shipboard paleomagnetic data alone. Archive-half core remanent inclination data are insufficient to allow accurate determination of changes in paleolatitude of the PSP (as suggested by previous workers; e.g., Yamazaki et al., 2010), as isolation of characteristic remanences in many intervals requires demagnetization to higher levels than can be achieved using shipboard systems. However, discrete samples analyzed during the expedition indicate that shore-based demagnetization of additional discrete samples will allow a robust determination of plate latitudinal motion. Discrete samples obtained from APC cores will provide additional constraints on plate rotation, as these cores were oriented using the FlexIT tool. Finally, postexpedition integration of remanence data and analysis of wireline Formation MicroScanner (FMS) logs may potentially allow magnetic declinations to be recovered in some deeper intervals, allowing plate rotation to be documented beyond $25 \mathrm{Ma}$.

\section{Physical properties}

Physical properties of recovered core were analyzed to help characterize lithostratigraphic units and provide the basis for linking the lithostratigraphy to the crossing seismic lines. Reflecting the compaction and lithification of sediments, there is an overall reduction in porosity through Units I-IV that fits with an exponential decay typical of that seen for shales, sandstones, and mudstones. There are significant jumps in sonic velocity, grain density, and magnetic susceptibility at the Unit I/II and II/III boundaries and oscillations in sonic velocity and magnetic susceptibility within the top of Unit III indicative of the changing proportions of sands and conglomerates to muds. Higher velocities are correlated to mudstones with clasts, and lower velocities are found in mudstones

Figure F16. Y vs. Zr for samples from a compilation of global MORB glasses (Jenner and O'Neill, 2012) compared to whole-rock basement samples from ODP Site 1201 (Savov et al., 2005), fore-arc basalts (FAB) from the Izu-BoninMariana fore arc (Reagan et al., 2010), and Unit 1 at Site U1438.

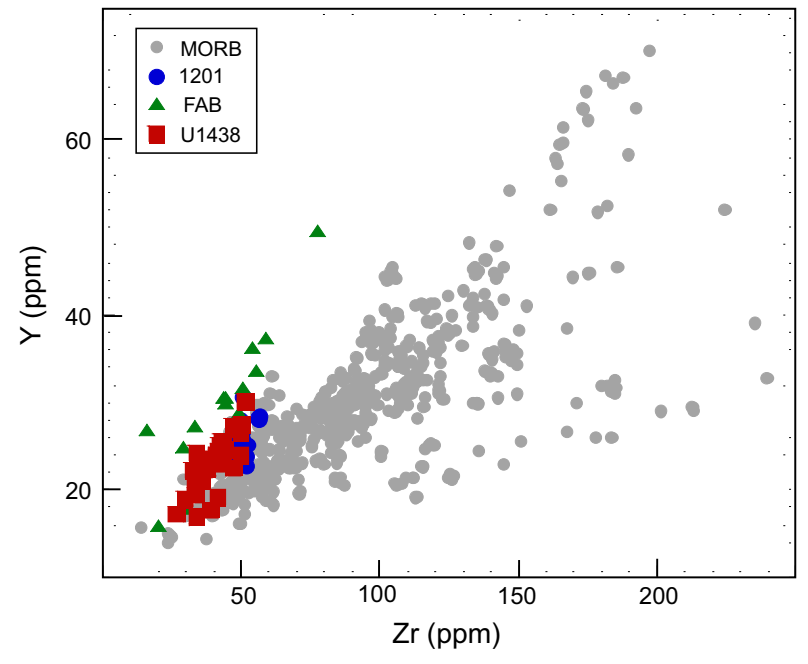


without clasts. These major changes occur between 160 and 300 mbsf (Holes U1438B and U1438D) and are likely responsible for the most prominent seismic reflectors seen in the crossing seismic lines of the site. Within Hole U1438E, the apparent anisotropy of sonic velocity was also measured. The azimuthal variation in sonic velocities are small, but the differences between the horizontal and the vertical velocities can be much larger and correlated with lithology; mudstones and fine sandstones with and without apparent bedding planes are generally more anisotropic than the coarser sandstones. There is also a prominent spike in the level of natural gamma radiation within Unit IV, most likely due to elevated concentrations of $U$, $\mathrm{Th}$, and $\mathrm{K}$.

Successful temperature measurements were made at seven depths using the advanced piston corer temperature tool (APCT-3) from the mudline to $83.2 \mathrm{mbsf}$, and these give a linear geothermal gradient without any substantial deviation from $77.6^{\circ} \mathrm{C} / \mathrm{km}$. Together with nearly constant values of thermal conductivity, it is concluded from this observation that the geotherm is undisturbed by local processes, such as sediment compaction, fluid flow within the porous sediments, and internal heat production from radioactive decay. The calculated heat flow is $73.7 \mathrm{~mW} / \mathrm{m}^{2}$, implying a thermal age for the underlying lithosphere of 40-60 Ma (Figure F17).

\section{Downhole measurements}

Logging occurred in three holes (U1438D, U1438E, and U1438F) over $1200 \mathrm{~m}$ of sediments, with the best interval between 100 and 700 mbsf. It covers an approximate age range of $40 \mathrm{My}$. Natural gamma radiation, resistivity, density, porosity, self-potential, magnetic susceptibility, sonic velocities, and magnetic orientation of the sediments were measured. In addition, resistivity images of the borehole were acquired and a seismic experiment was organized.

Three major transitions in the logging data were described. The first one at 160 mbsf corresponds to lithostratigraphic Unit I. This interval is characterized by (1) high gamma ray values (with particularly high thorium and uranium concentrations); (2) mean density of $1.3 \mathrm{~g} / \mathrm{cm}^{3}$; (3) very high porosity (>80\%); and (4) low magnetic susceptibility, resistivity, velocity $(\sim 1800 \mathrm{~m} / \mathrm{s})$, and self-potential values. The second interval is located between 160 and $300 \mathrm{mbsf}$, corresponding to lithostratigraphic Unit II. This interval is characterized by an overall increase in sonic velocity, magnetic susceptibility, density, and self-potential. Gamma radiation becomes weak. Thorium and uranium decrease to concentration values $<1 \mathrm{ppm}$ in that depth interval. Porosity also decreases slightly; however, this may be due to changes in borehole diameter.

The last major interval is $300-1200 \mathrm{mbsf}$ and can be divided into subunits. Overall, this unit is characterized by (1) a decrease of porosity from $80 \%$ to $50 \%$, (2) an important decrease in self-potential, (3) low values of gamma ray (around 20 gAPI with a slight increase at $500 \mathrm{mbsf}$ ), (4) a large increase in resistivity (from $1 \Omega \mathrm{m}$ to an average value of $3.5 \Omega \mathrm{m}$ ), (5) an increase to velocity values around $2500 \mathrm{~m} / \mathrm{s}$, and (6) a large increase in magnetic susceptibility values.

The logging data have been compared with measurements made on cores and with the lithostratigraphic units, where they correlate well. Furthermore, the logging data will fill in the gaps where core recovery is lower $(<100 \%)$. The FMS images display bedding features that will be reoriented and help characterize the source of mass wasting deposits described in the cores. Finally, downhole sonic velocities agree well with core measurements and will allow the construction of a seismic traveltime-depth relationship for Site U1438 and thus provide characterization of seismic boundaries.

\section{Preliminary scientific assessment}

Expedition 351 was conceptually straightforward, targeting a single site (U1438) in the ASB, west of the KPR, a remnant arc of the intraoceanic IBM arc. Drilling penetrated a thick sediment section overlying igneous oceanic crust of normal thickness; nevertheless, the water depth $(4700 \mathrm{~m})$, sediment thickness $(1461 \mathrm{~m})$, and consequent depth to basement were technically challenging. In fact, the fourth longest drill string ever deployed by the JOIDES Resolution in the history of ODP/Integrated Ocean Drilling Program/IODP was deployed during Expedition 351. Despite these challenges, Expedition 351 was remarkably successful. We recovered the entire sedi-

Figure F17. Downhole temperature, thermal conductivity, thermal resistance, and Bullard plots, Hole U1438A.
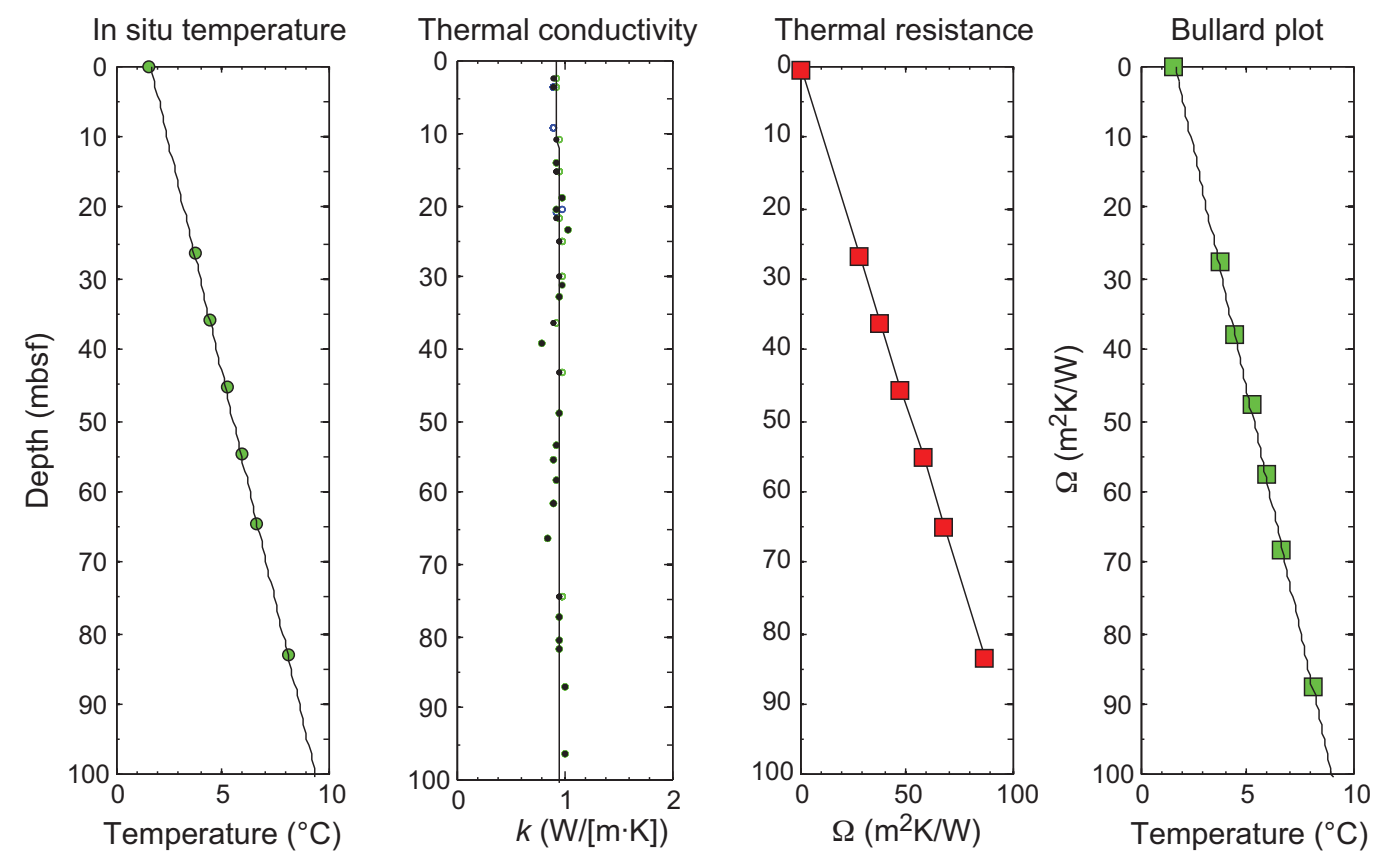
mentary section of the basin and cored $150 \mathrm{~m}$ of subjacent igneous oceanic basement.

Expedition 351 has given us an increased understanding of subduction initiation and subsequent arc maturation that has led to critically important new insights into these topics. All of the primary science objectives were achieved, as well as the majority of the secondary objectives. Below, we assess these objectives and highlight major results.

\section{Primary objectives}

\section{Determine the nature of the original crust and mantle that ex- isted in the region prior to the beginning of subduction in the middle Eocene}

An essential boundary condition for understanding the evolution of island arcs is to know the composition, structure, and age of the crust and mantle that existed before subduction began. In the northern IBM case, fortuitously, the preexisting oceanic crust exists under $1-1.5 \mathrm{~km}$ of sediment in the ASB adjacent to the KPR remnant arc and perhaps also crops out on the lower fore-arc slope of the Bonin Trench (DeBari et al., 1999; Ishizuka et al., 2011a), making possible access to samples of the pre-arc igneous oceanic basement upon which the arc was constructed.

Site U1438 successfully reached the sediment/basement contact at $1461 \mathrm{mbsf}$ and recovered igneous basement of the ASB. The igneous basement comprises a sequence of basaltic lava flows. Although the basaltic lavas have variable degrees of alteration, they are sufficiently fresh for a variety of petrological, geochemical, and geochronological investigations to determine successfully and comprehensively the nature of the oceanic crust and the critical characteristics of the mantle source(s) from which the basalts were derived.

Decoding the nature of the magma source in the upper mantle that existed immediately before IBM arc initiation is a key to understanding the cause of the initiation of subduction zones and intraoceanic arc formation. Absolute trace element abundances together with ratios of these and various isotopic indicators of the basement rocks will be utilized to quantify models of interaction between ascending IBM arc magmas and the basement.

We have found the basement lava flows are high-MgO (mostly $>8 \mathrm{wt} \%$ ) (Figure F15), low- $\mathrm{TiO}_{2}(0.6-1.1 \mathrm{wt} \%)$, low- $\mathrm{Zr}$ (mostly $<50$ ppm) (Figure F16), high-Sc (mostly $>40 \mathrm{ppm}$ ), and high-Cr (up to $\sim 400 \mathrm{ppm}$ ) Cr spinel + olivine + plagioclase + clinopyroxene $+\mathrm{mi}-$ crophyric tholeiitic basalts. These basalts are compositionally very similar to the $\sim 49$ Ma basalts recovered during ODP Leg 195, Hole 1201D, in the WPB (Savov et al., 2005) and the $~ 52$ Ma FAB recovered from the present-day Izu-Bonin Trench wall (Reagan et al., 2010; Ishizuka et al., 2011a). Compared with global mid-oceanridge basalt compositions (Jenner and O'Neill, 2012), Hole U1438E basalts have high $\mathrm{MgO} / \mathrm{FeO}$, with markedly low $\mathrm{TiO}_{2}$, low $\mathrm{Zr}$, and high Sc abundances; they are relatively primitive melts and likely derived from upper mantle sources that are more strongly depleted in terms of magmaphile trace elements than those typically tapped beneath mid-ocean ridges. Depending on the absolute age of the basement (Unit 1) at Site U1438 and further compositional comparisons with the earliest basalt-boninite sequences exposed in the current IBM fore arc, our conceptions of the nature of arc inception and earliest arc development will change. For example, we will explore the processes that develop a continuum from widespread earliest high-MgO tholeiitic magmatism in an extensional environment forming the basement, through boninite, to isolated topographically prominent arc volcanoes developed within the lateral confines of this basement.

\section{Identify and model the process of subduction initiation and ini- tial arc crust formation}

Understanding the response of the overriding plate during the initial stages in formation of the new subduction zone is essential for testing first-order competing proposals for subduction initiation. The sediment section overlying the igneous basement of the ASB was expected to preserve evidence for processes associated with subduction initiation. Different responses of the overriding plate during the initial stages of subduction initiation were predicted to result from either forced convergence (uplift) or spontaneous nucleation of the subduction zone.

The character of the earliest juvenile magmatic outputs of the nascent IBM arc recovered from the sedimentary sequence at Site U1438 is of first-order importance for (1) constraining the composition of the mantle wedge at this stage of arc development, (2) determining the nature of subducted inputs, and (3) comparing with the magmatic sequences recovered so far by drilling and dredging in the current fore arc (e.g., Reagan et al., 2010) to be sought during Expedition 352 . We have an opportunity to explore possible across-strike variations in the nature of juvenile arc magmatic outputs and to establish whether the sequence recognized for the fore arc from earliest MORB-like FAB through boninite to the temporally more enduring and apparently stable output of island arc tholeiitic types also existed at the western margin of the earliest IBM arc.

The recovery of an extensive sediment sequence of early Eocene age in Unit IV at Site U1438, coeval with the currently understood initiation of the IBM arc at $\sim 52 \mathrm{Ma}$ (Figure F13) will allow comprehensive analysis of the provenance, geochemical and petrological characteristics, and style of earliest arc magmatic activity. The geochemical and petrological equivalence of the lithostratigraphic Unit 1 lava flows with the IBM FAB has critical implications regarding the style of magmatism accompanying arc inception and the lateral (across-strike) extent of this type of igneous activity. The apparent absence of boninites at Site U1438, however, may indicate petrologic provinciality was established within the first few million years of the IBM arc's existence.

\section{Determine the compositional evolution during the Paleogene of the IBM arc}

The complete tephra record of fore-arc/arc/back-arc volcanism subsequent to arc initiation in the middle Eocene to the isolation of the KPR as a remnant arc accompanying inception of the Shikoku back-arc basin at $\sim 25 \mathrm{Ma}$ (and possibly sporadically thereafter) was obtained at Site U1438. Comprehensive analytical data exist for Neogene ash and pyroclastic materials recovered from the IBM fore arc (e.g., Bryant et al., 1999; Straub, 2003; Straub et al., 2004) and indicate remarkable stability (a function of subducted slab inputs, mantle wedge replenishment, and overriding plate inputs) of the northern part of this system, but the Paleogene record is sparse. In combination with the known Eocene and younger lava/plutonic products (Haraguchi et al., 2003; Ishizuka et al., 2011b), the ash and pyroclast record during this interval will allow us to determine the output variation through time transect across-arc of the northern IBM arc compared to Pacific plate inputs.

The voluminous volcaniclastic materials recovered from the Eocene through Oligocene sequence of Units II, III, and IV, in sediments varying from silt through sand to gravel, contain sufficiently fresh glass (at least in the shallower section) and igneous minerals to 
allow comprehensive postexpedition petrological and geochemical studies to satisfy this third primary objective. Noteworthy features of the mineral assemblage are the persistent occurrence of amphibole. This phase is rare in the tephra recovered from previously drilled sites in the IBM fore arc and may indicate significant acrossstrike compositional variability of magma composition was established early in the Paleogene.

\section{Establish geophysical properties of the ASB}

The basement of the IBM arc comprises sedimentary and underlying igneous rock types accessible for direct geophysical measurements through study of recovered cores and downhole logging at Site U1438. With heat flow measurements at Site U1438, we have been able to establish the thermal age of the lithosphere (Figure F17). The geothermal gradient is $77.6^{\circ} \mathrm{C} / \mathrm{km}$, and the heat flux is $73.7 \mathrm{~mW} / \mathrm{m}^{2}$, implying a thermal age of $40-60 \mathrm{Ma}$ (Sclater et al., 1980). This result will become even more important once the geochronological age of lithostratigraphic Unit 1 is established. The thermal age is important to ascertain the initial mechanical properties at the time of subduction initiation and to better inform estimates of initial water depth and subsequent bathymetric evolution. The thermal age is young compared to previous suggestions and implies a near zero age and extremely low plate strength during the initiation of subduction. Existing plate tectonic models position the Pacific plate (with an age of $\sim 50 \mathrm{Ma}$ at that time) on the other side of the nascent KPR during subduction initiation. With a thermal age of $\sim 50 \mathrm{Ma}$ today for the ASB, a substantial age difference would have existed across the new subduction boundary.

A preliminary estimate of the sediment load-corrected depth of the basement at Site U1438 gives a depth of $~ 5527$ mbsf; with an expected depth of $5000 \mathrm{mbsf}$ for a $50 \mathrm{Ma}$ age plate (Sclater et al., 1980), a residual depth of $\sim 550 \mathrm{~m}$ is calculated. This is consistent with other estimates for the PSP, which have excess depths of 400$600 \mathrm{~m}$ (Flament et al., 2013). These depths are consistent with predictions of dynamic topography from mantle flow that have such depths for the PSP. The excess depth for the region provides an explanation for the lack of calcareous fossils through much of the core and why the region was below the CCD. If the basement has an age of about $50 \mathrm{Ma}$, then we would have expected intervals of time from about 40-45 Ma when our sediment column would have been above the CCD (Palike et al., 2012). Dynamic subsidence since the time of subduction initiation (Gurnis, 1992) would provide a natural explanation for the sub-CCD depths.

Basement logging was not achieved at Site U1438, but $1200 \mathrm{~m}$ of logs were obtained, recovering a maximum age equivalent to $\sim 40$ Ma. The best coverage is from 100 to 700 mbsf ( 35 Ma). The logs (gamma radiation, velocity, density, porosity, resistivity, and magnetic susceptibility) were correlated with lithostratigraphic units. The FMS images display bedding and other features that may help characterize the large-scale tectonic development of the ASB. Additionally, orientation of these structures might help characterize the source of the mass wasting deposits described in some of the cores. Sonic data (vertical seismic images and P-wave velocity) and density data from logs and cores give a time-depth relationship for the site and thus provide characterization of seismic boundaries. We will thus be able to make accurate tie-points between core/log data and seismic data, which will help to understand the general nature of the ASB in particular and the velocity structure of the IBM system more generally.

There has been a long-standing debate concerning the initial geographic orientation and location of the IBM system during sub- duction initiation (argued to be $\sim 090^{\circ}$ ) and its subsequent postulated $90^{\circ}$ clockwise rotation to a present-day north-south strike during 50 My (Hall et al., 1995; Yamazaki et al., 2010; Richter and Ali, 2015). The initial orientation of the IBM system and any subsequent rotations are important with respect to establishing the boundary conditions for subduction initiation and later plate interactions. Archive-half core remanent inclination data produced during this expedition are insufficient to allow accurate determination of changes in paleolatitude of the PSP (as suggested by previous workers; e.g., Yamazaki et al., 2010), as isolation of characteristic remanences in many intervals requires demagnetization to higher levels than can be achieved using shipboard systems. However, analyses of additional discrete sample demagnetization postexpedition will allow a robust determination of plate latitudinal motion. Discrete samples obtained from APC cores will provide additional constraints on plate rotation, as these cores were oriented using the FlexIT tool. Finally, postcruise integration of remanence data and analysis of wireline FMS logs may potentially allow magnetic declinations to be recovered in some deeper intervals, allowing plate rotation to be documented beyond $25 \mathrm{Ma}$.

\section{Secondary objectives}

\section{Recover sedimentary records of paleoceanographic conditions from Pliocene-Pleistocene to early Tertiary and possibly Late Cretaceous in the eastern Tethys-western Pacific}

The paleographic position of the ASB adjacent to Cretaceousage arcs and back-arc basins had the potential to provide an excellent opportunity to recover records of paleoceanographic conditions in the far eastern Tethys-western Pacific in the Late Cretaceous (and possibly older) through the Paleogene. Among the opportunities were the transection of the Cretaceous/Paleocene boundary, the organic-rich shales of ocean anoxic events, the Paleocene/Eocene Thermal Maximum, and Eocene hyperthermals. However, the oldest sediments recovered at Site U1438, immediately overlying the igneous basement, are $\sim 50-53 \mathrm{Ma}$. This result has critical significance in terms of achieving the primary objectives of Expedition 351 (see above), but means that none of the objectives related to the recovery of Cretaceous or older Paleogene sedimentary rocks could be realized. Despite not recovering sedimentary records of climate intervals/events, the quality of the cores obtained indicates an excellent Neogene paleoceanographic sedimentary record. In particular, the Oligocene-Miocene transition and sediments deposited during the mid-Miocene climatic optimum were recovered. The Eocene/Oligocene boundary and a high-resolution record of Pliocene-Pleistocene environmental changes will also provide exciting opportunities for paleoclimate studies.

\section{Recover sedimentary records of onset and persistence of the East Asian Monsoon and other climate-modulated land-sea correla- tions}

Integrated Ocean Drilling Program Expedition 346 conducted two latitudinal transects to test hypotheses concerning tectonic linkages with the onset of the Asian Monsoon. Site U1438 is located southeast of these sites and may be complementary to them. Although our site is distal from the point of Yangtze River discharge, evidence of fluvial input is possible. More likely, eolian inputs to the ASB, such as loess from East Asia, dominate the terrestrial signal. High-quality cores recovered from Site U1438 span the Miocene to recent, include a large clay fraction, and should provide a complete record of East Asian monsoon onset and intensity changes over a 
long timescale. This will provide important information regarding timing and geographic distribution of terrestrial material in the western Pacific marine record.

\section{Recover an ash record of the evolution of the Ryukyu-Kyushu arc}

Subduction of the PSP, on which the ASB now is situated, takes place in part along the Ryukyu-Kyushu arc to the northwest of Site U1438. We anticipated an ash record from this arc to be preserved within the sediments. Some particularly significant explosive events from the Ryukyu-Kyushu arc produced extensive ash deposits that are used as critical stratigraphic marker horizons in the Japanese islands. In addition to this feature, the temporal evolution of the Ryukyu-Kyushu arc located on the East Asian continental margin will provide important complementary evidence of arc evolution with the IBM system.

Numerous layers of volcanic ash were recovered in the recent to Miocene sediments of the uppermost Unit I at Site U1438, comprising fresh glass shards and igneous minerals; layers range in thickness from 1 to $13 \mathrm{~cm}$ and in grain size up to lapilli. The pyroclastic components are dominantly colorless vitric pumice and shards with traces of brown vitric fragments. Phenocrysts and isolated volcanogenic crystals include pyroxene, opaque minerals, plagioclase, minor biotite, and quartz. Some ash fractions are notably enriched in lithic fragments and crystals. Comparison with glass and mineral compositions with published data for the Ryukyu-Kyushu, Honshu, and Neogene IBM arcs will permit identification of the sources of volcanic ash at Site U1438. An opportunity exists with good age constraints to provide new physical volcanogenic data for modeling volumes, explosivity, and geochemical properties of the explosive output of the respective arcs surrounding the ASB.

\section{References}

Arculus, R.J., Johnson, R.W., Chappell, B.W., McKee, C.O., and Sakai, H., 1983. Ophiolite-contaminated andesites, trachybasalts, and cognate inclusions of Mount Lamington, Papua New Guinea: anhydrite-amphibole-bearing lavas and the 1951 cumulodome. Journal of Volcanology and Geothermal Research, 18(1-4):215-247. http://dx.doi.org/10.1016/0377-0273(83)90010-0

Bloomer, S.H., Stern, R.J., Fisk, E., and Geschwind, C.H., 1989. Shoshonitic volcanism in the northern Mariana arc, 1. Mineralogy and major and trace element characteristics. Journal of Geophysical Research: Solid Earth, 94(B4):4469-4496. http://dx.doi.org/10.1029/JB094iB04p04469

Bryant, C.J., Arculus, R.J., and Eggins, S.M., 1999. Laser ablation-inductively coupled plasma-mass spectrometry and tephras: a new approach to understanding arc-magma genesis. Geology, 27(12):1119-1122. http://dx.doi.org/10.1130/0091-7613(1999)027<1119:LAICPM>2.3 .CO;2

Buchs, D.M., Arculus, R.J., Baumgartner, P.O., Baumgartner-Mora, C., and Ulianov, A., 2010. Late Cretaceous arc development on the SW margin of the Caribbean plate: insights from the Golfito, Costa Rica, and Azuero, Panama, complexes. Geochemistry, Geophysics, Geosystems, 11(7):Q07S24. http://dx.doi.org/10.1029/2009GC002901

Cannat, M., Sauter, D., Mendel, V., Ruellan, E., Okino, K., Escartin, J., Combier, V., and Baala, M., 2006. Modes of seafloor generation at a melt-poor ultraslow-spreading ridge. Geology, 34(7):605-608. http://dx.doi.org/10.1130/G22486.1

Casey, J.F., and Dewey, J.F., 1984. Initiation of subduction zones along transform and accreting plate boundaries, triple-junction evolution, and forearc spreading centres-implications for ophiolitic geology and obduction. In Gass, I.G., Lippard, S.J., and Shelton, A.W. (Eds.), Ophiolites and Oceanic Lithosphere. Geological Society Special Publication, 13:269-290. http://dx.doi.org/10.1144/GSL.SP.1984.013.01.22
Cosca, M.A., Arculus, R.J., Pearce, J.A., and Mitchell, J.G., $1998 .{ }^{40} \mathrm{Ar} /{ }^{39} \mathrm{Ar}$ and $\mathrm{K}-\mathrm{Ar}$ geochronological age constraints for the inception and early evolution of the Izu-Bonin-Mariana arc system. Island Arc, 7(3):579-595. http://dx.doi.org/10.1111/j.1440-1738.1998.00211.x

Crawford, A.J., Meffre, S., and Symonds, P.A., 2003. 120 to 0 Ma tectonic evolution of the southwest Pacific and analogous geological evolution of the 600 to 220 Ma Tasman fold belt system. In Hillis, R.R., and Müller, R.D. (Eds.), Evolution and Dynamics of the Australian Plate. Special PaperGeological Society of America, 372:383-403. http://dx.doi.org/10.1130/0-8137-2372-8.383

Davidson, J.P., and Arculus, R.J., 2006. The significance of Phanerozoic arc magmatism in generating continental crust. In Brown, M., and Rushmer, T. (Eds.), Evolution and Differentiation of the Continental Crust: Cambridge, UK (Cambridge University Press), 135-172.

DeBari, S.M., Taylor, B., Spencer, K., and Fujioka, K., 1999. A trapped Philippine Sea plate origin for MORB from the inner slope of the Izu-Bonin Trench. Earth and Planetary Science Letters, 174(1-2):183-197. http://dx.doi.org/10.1016/S0012-821X(99)00252-6

Deschamps, A., and Lallemand, S., 2002. The West Philippine Basin: an Eocene to early Oligocene backarc basin opened between two opposed subduction zones. Journal of Geophysical Research: Solid Earth, 107(B12):2322. http://dx.doi.org/10.1029/2001JB001706

Deschamps, A., and Lallemand, S., 2003. Geodynamic setting of Izu-BoninMariana boninites. In Larter, R.D., and Leat, P.H. (Eds), Intra-Oceanic Subduction Systems: Tectonic and Magmatic Processes. Geological Society Special Publication, 219:163-185.

http://dx.doi.org/10.1144/GSL.SP.2003.219.01.08

Deschamps, A., Monié, P., Lallemand, S., Hsu, S.-K., and Yeh, K.Y., 2000. Evidence for Early Cretaceous oceanic crust trapped in the Philippine Sea plate. Earth and Planetary Science Letters, 179(3-4):503-516. http://dx.doi.org/10.1016/S0012-821X(00)00136-9

Deschamps, A., Okino, K., and Fujioka, K., 2002. Late amagmatic extension along the central and eastern segments of the West Philippine Basin fossil spreading axis. Earth and Planetary Science Letters, 203(1):277-293. http://dx.doi.org/10.1016/S0012-821X(02)00855-5

Deschamps, A., Shinjo, R., Matsumoto, T., Lee, C.-S., Lallemand, S.E., Wu, S., and the Scientific Party of KR03-04 and KR04-14 Cruises, 2008. Propagators and ridge jumps in a back-arc basin, the West Philippine Basin. Terra Nova, 20(4):327-332. http://dx.doi.org/10.1111/j.13653121.2008.00824.x

Flament, N., Gurnis, M., and Müller, R.D., 2013. A review of observations and models of dynamic topography. Lithosphere, 5(2):189-210. http://dx.doi.org/10.1130/L245.1

Fliedner, M.M., and Klemperer, S.L., 2000. Crustal structure transition from oceanic arc to continental arc, eastern Aleutian Islands and Alaska Peninsula. Earth and Planetary Science Letters, 179(3-4):567-579. http://dx.doi.org/10.1016/S0012-821X(00)00142-4

Fujioka, K., Kanamatsu, T., Sasaki, A., Ohara, Y., Sakamoto, I., Haraguchi, S., and Ishii, T., 1997. Morphology and geology of extinct spreading center in the Philippine Sea plate-results of the Yokosuka Y96-11 cruise. JAMSTEC Journal of Deep Sea Research, 13:155-194.

Fujioka, K., Okino, K., Kanamatsu, T., Ohara, Y., Ishizuka, O., Haraguchi, S., and Ishii, T., 1999. Enigmatic extinct spreading center in the west Philippine backarc basin unveiled. Geology, 27(12):1135-1138. http://dx.doi.org/10.1130/0091-7613(1999)027<1135:EESCIT>2.3. $\mathrm{CO} ; 2$

Gale, A., Dalton, C.A., Langmuir, C.H., Su, Y., and Schilling, J.-G., 2013. The mean composition of ocean ridge basalts. Geochemistry, Geophysics, Geosystems, 14(3):489-518. http://dx.doi.org/10.1029/2012GC004334

Gurnis, M., 1992. Rapid continental subsidence following the initiation and evolution of subduction. Science, 255(5051):1556-1558. http://dx.doi.org/10.1126/science.255.5051.1556

Gurnis, M., Hall, C., and Lavier, L., 2004. Evolving force balance during incipient subduction. Geochemistry, Geophysics, Geosystems, 5(7):Q07001. http://dx.doi.org/10.1029/2003GC000681

Hall, C.E., Gurnis, M., Sdrolias, M., Lavier, L.L., and Dietmar Müller, R., 2003. Catastrophic initiation of subduction following forced convergence across 
fracture zones. Earth and Planetary Science Letters, 212(1-2):15-30. http://dx.doi.org/10.1016/S0012-821X(03)00242-5

Hall, R., 2002. Cenozoic geological and plate tectonic evolution of SE Asia and the SW Pacific: computer-based reconstructions, model and animations. Journal of Asian Earth Sciences, 20(4):353-431. http://dx.doi.org/10.1016/S1367-9120(01)00069-4

Hall, R., Ali, J.R., Anderson, C.D., and Baker, S.J., 1995. Origin and motion history of the Philippine Sea plate. Tectonophysics, 251(1-4):229-250. http://dx.doi.org/10.1016/0040-1951(95)00038-0

Haraguchi, S., Ishii, T., Kimura, J.-I., and Ohara, Y., 2003. Formation of tonalite from basaltic magma at the Komahashi-Daini Seamount, northern Kyushu-Palau Ridge in the Philippine Sea, and growth of Izu-Ogasawara (Bonin)-Mariana arc crust. Contributions to Mineralogy and Petrology, 145(2):151-168. http://dx.doi.org/10.1007/s00410-002-0433-y

Hickey-Vargas, R., 1998a. Geochemical characteristics of oceanic island basalts from the Philippine Sea plate: implications for the sources of Southeast Asian plate margin and intraplate basalts. In Flower, M.F.J., Chung, S.-L., Lo, C.H., and Lee, T.-Y. (Eds.), Mantle Dynamics and Plate Interactions in East Asia. AGU Geodynamics Series, 27:36-384. http://onlinelibrary.wiley.com/doi/10.1029/GD027p0365/summary

Hickey-Vargas, R., 1998b. Origin of the Indian Ocean-type isotopic signature in basalts from Philippine Sea plate spreading centers: an assessment of local versus large-scale processes. Journal of Geophysical Research: Solid Earth, 103(B9):20963-20979. http://dx.doi.org/10.1029/98JB02052

Hickey-Vargas, R., 2005. Basalt and tonalite from the Amami Plateau, northern West Philippine Basin: new Early Cretaceous ages and geochemical results, and their petrologic and tectonic implications. Island Arc, 14(4):653-665. http://dx.doi.org/10.1111/j.1440-1738.2005.00474.x

Hickey-Vargas, R., Bizimis, M., and Deschamps, A., 2008. Onset of the Indian Ocean isotopic signature in the Philippine Sea plate: $\mathrm{Hf}$ and $\mathrm{Pb}$ isotope evidence from Early Cretaceous terranes. Earth and Planetary Science Letters, 268(3-4):255-267. http://dx.doi.org/10.1016/j.epsl.2008.01.003

Higuchi, Y., Yanagimoto, Y., Hoshi, K., Unou, S., Akiba, F., Tonoike, K., and Koda, K., 2007. Cenozoic stratigraphy and sedimentation history of the northern Philippine Sea based on multichannel seismic reflection data. Island Arc, 16(3):374-393. http://dx.doi.org/10.1111/j.14401738.2007.00588.x

Hilde, T.W.C., and Lee, C.-S., 1984. Origin and evolution of the west Philippine Basin: a new interpretation. Tectonophysics, 102(1-4):85-104. http://dx.doi.org/10.1016/0040-1951(84)90009-X

Hofmann, A.W., 1997. Mantle geochemistry: the message from oceanic volcanism. Nature, 385(6613):219-229. http://dx.doi.org/10.1038/385219a0

House, M.A., Gurnis, M., Kamp, P.J.J., and Sutherland, R., 2002. Uplift in the Fiordland region, New Zealand: implications for incipient subduction. Science, 297(5589):2038-2041. http://dx.doi.org/10.1126/science.1075328

Ishizuka, O., Kimura, J.-I., Li, Y.B., Stern, R.J., Reagan, M.K., Taylor, R.N., Ohara, Y., Bloomer, S.H., Ishii, T., Hargrove, U.S., III, and Haraguchi, S., 2006a. Early stages in the evolution of Izu-Bonin arc volcanism: new age, chemical, and isotopic constraints. Earth and Planetary Science Letters, 250(1-2):385-401. http://dx.doi.org/10.1016/j.epsl.2006.08.007

Ishizuka, O., Tani, K., Reagan, M.K., Kanayama, K., Umino, S., Harigane, Y., Sakamoto, I., Miyajima, Y., Yuasa, M., and Dunkley, D.J., 2011a. The timescales of subduction initiation and subsequent evolution of an oceanic island arc. Earth and Planetary Science Letters, 306(3-4):229-240. http://dx.doi.org/10.1016/j.epsl.2011.04.006

Ishizuka, O., Taylor, R.N., Milton, J.A., and Nesbitt, R.W., 2003. Fluid-mantle interaction in an intraoceanic arc: constraints from high-precision $\mathrm{Pb}$ isotopes. Earth and Planetary Science Letters, 211(3-4):221-236. http://dx.doi.org/10.1016/S0012-821X(03)00201-2

Ishizuka, O., Taylor, R.N., Milton, J.A., Nesbitt, R.W., Yuasa, M., and Sakamoto, I., 2006b. Variation in the mantle sources of the northern Izu arc with time and space-constraints from high-precision $\mathrm{Pb}$ isotopes. Journal of Volcanology and Geothermal Research, 156(3-4):266-290. http://dx.doi.org/10.1016/j.jvolgeores.2006.03.005
Ishizuka, O., Taylor, R.N., Ohara, Y., and Yuasa, M., 2013. Upwelling, rifting, and age-progressive magmatism from the Oki-Daito mantle plume. Geology, 41(9):1011-1014. http://dx.doi.org/10.1130/G34525.1

Ishizuka, O., Taylor, R.N., Yuasa, M., Milton, J.A., Nesbitt, R.W., Uto, K., and Sakamoto, I., 2007. Processes controlling along-arc isotopic variation of the southern Izu-Bonin arc. Geochemistry, Geophysics, Geosystems, 8(6):Q06008. http://dx.doi.org/10.1029/2006GC001475

Ishizuka, O., Taylor, R.N., Yuasa, M., and Ohara, Y., 2011b. Making and breaking an island arc: a new perspective from the Oligocene Kyushu-Palau arc, Philippine Sea. Geochemistry, Geophysics, Geosystems, 12(5):Q05005. http://dx.doi.org/10.1029/2010GC003440

Japan National Oil Corporation, 1998. Technology Research Center Report: Deep Sea Survey Technologies for Natural Resources. (in Japanese)

Jenner, F.E., and O'Neill, H.St.C., 2012. Analysis of 60 elements in 616 ocean floor basaltic glasses. Geochemistry, Geophysics, Geosystems, 13(2):Q02005. http://dx.doi.org/10.1029/2011GC004009

Jolivet, L., Huchon, P., and Rangin, C., 1989. Tectonic setting of Western Pacific marginal basins. Tectonophysics, 160(1-4):23-47. http://dx.doi.org/10.1016/0040-1951(89)90382-X

Karig, D.E., Ingle, J.C., Jr., et al., 1975. Initial Reports of the Deep Sea Drilling Project, 31: Washington, DC (U.S. Govt. Printing Office). http://dx.doi.org/10.2973/dsdp.proc.31.1975

Kempton, P.D., Pearce, J.A., Barry, T.L., Fitton, J.G., Langmuir, C., and Christie, D.M., 2002. Sr-Nd-Pb-Hf isotope results from ODP Leg 187: evidence for mantle dynamics of the Australian-Antarctic Discordance and origin of Indian MORB source. Geochemistry, Geophysics, Geosystems, 3(12):1074. http://dx.doi.org/10.1029/2002GC000320

Kodaira, S., Sato, T., Takahashi, N., Ito, A., Tamura, Y., Tatsumi, Y., and Kaneda, Y., 2007. Seismological evidence for variable growth of crust along the Izu intraoceanic arc. Journal of Geophysical Research: Solid Earth, 112(B5):B05104. http://dx.doi.org/10.1029/2006JB004593

Le Pichon, X., Huchon, Ph., and Barrier, E., 1985. Pangea, geoid and the evolution of the western margin of the Pacific ocean: In Nasu, N., Uyeda, S., Kobayashi, K., Kushiro, I., and Kagami, H. (Eds.), Formation of Active Ocean Margins: Tokyo (Terra Scientific Publishing,), 3-42.

Leng, W., Gurnis, M., and Asimow, P., 2012. From basalts to boninites: the geodynamics of volcanic expression during induced subduction initiation. Lithosphere, 4(6):511-523. http://dx.doi.org/10.1130/L215.1

Lewis, S.D., Hayes, D.E., and Mrozowski, C.L., 1982. The origin of the West Philippine Basin by interarc spreading. In Balce, G.R., and Zanoria, A.S. (Eds.), Geology and Tectonics of the Luzon-Marianas Region. Philippine SEATAR Committee Special Publication, 1:31-51.

Machida, H., 1999. The stratigraphy, chronology and distribution of distal marker-tephras in and around Japan. Global and Planetary Change, 21(1-3):71-94. http://dx.doi.org/10.1016/S0921-8181(99)00008-9

Macpherson, C.G., and Hall, R. 2001. Tectonic setting of Eocene boninite magmatism in the Izu-Bonin-Mariana forearc. Earth and Planetary Science Letters, 186(2):215-230. http://dx.doi.org/10.1016/S0012821X(01)00248-5

Mahoney, J.J., Frei, R., Tejada, M.L.G., Mo, X.X., Leat, P.T., and Nägler, T.F., 1998. Tracing the Indian Ocean mantle domain through time: isotopic results from old west Indian, east Tethyan and South Pacific seafloor. Journal of Petrology, 39(7):1285-1306. http://petrology.oxfordjournals.org/cgi/content/abstract/39/7/128 5

Matsuda, J., Saito, K., and Zasu, S., 1975. K-Ar age and Sr isotope ratio of the rocks in the manganese nodules obtained from the Amami plateau, western Philippine Sea. In Symposium on Geological Problems of the Philippine Sea: Tokyo (Geological Society of Japan), 99-101.

McKenzie, D.P., 1977. The initiation of trenches: a finite amplitude instability. In Talwani, M., and Pitman, W.C., IIII (Eds.), Island Arcs, Deep Sea Trenches and Back-Arc Basins. Maurice Ewing Series, 1:57-61. http://onlinelibrary.wiley.com/doi/10.1029/ME001p0057/summary

Mizuno, A., Okuda, Y., Nagumo, S., Kagami, H., and Nasu, N., 1978. Subsidence of the Daito Ridge and associated basins, north Philippine Sea. AAPG Memoir, 29:239-243. 
http://archives.datapages.com/data/specpubs/history2/images/a10 9/a1090001/0200/02390.pdf

Mizuno, A., Okuda, Y., Tamaki, K., Kinoshita, Y., Nohara, M., Yuasa, M., Nakajima, N., Murakami, F., Terashima, S., and Ishibashi, K., 1975. Marine geology and geologic history of the Daito Ridges area, northwestern Philippine Sea. Marine Science Monthly, 7:484-491. (in Japanese)

Mizuno, A., Shibata, K., Uchiumi, S., Yuasa, M., Okuda, Y., Nohara, M., and Kinoshita, Y., 1977. Granodiorite from the Minami-koho Seamount on the Kyushu-Palau Ridge, and its K-Ar age. Bulletin of the Geological Survey of Japan, 28(8):5-9.

Mueller, S., and Phillips, R.J., 1991. On the initiation of subduction. Journal of Geophysical Research: Solid Earth, 96(B1):651-665. http://dx.doi.org/10.1029/90JB02237

Nishizawa, A., Kaneda, K., Katagiri, Y., and Oikawa, M., 2014. Wide-angle refraction experiments in the Daito Ridges region at the northwestern end of the Philippine Sea plate. Earth, Planets and Space, 66(1):25. http://dx.doi.org/10.1186/1880-5981-66-25

Okino, K., and Fujioka, K., 2003. The Central Basin spreading center in the Philippine Sea: structure of an extinct spreading center and implications for marginal basin formation. Journal of Geophysical Research: Solid Earth, 108(B1):2040. http://dx.doi.org/10.1029/2001JB001095

Okino, Y., Shimakawa, Y., and Nagaoka, S., 1994. Evolution of the Shikoku Basin. Journal of Geomagnetism and Geoelectricity, 46(6):463-479. http://dx.doi.org/10.5636/jgg.46.463

Pälike, H., Lyle, M.W., Nishi, H., Raffi, I., Ridgwell, A., Gamage, K., Klaus, A., Acton, G., Anderson, L., Backman, J., Baldauf, J., Beltran, C., Bohaty, S.M. Bown, P., Busch, W., Channell, J.E.T., Chun, C.O.J., Delaney, M., Dewangan, P., Dunkley Jones, T., Edgar, K.M., Evans, H., Fitch, P., Foster, G,L., Gussone, N., Hasegawa, H., Hathorne, E.C., Hayashi, H., Herrle, J.O., Holbourn, A., Hovan, S., Hyeong, K., Iijima, K., Ito, T., Kamikuri, S., Kimoto, K., Kuroda, J., Leon-Rodriguez, L., Malinverno, A., Moore, T.C., Jr., Murphy, B.H., Murphy, D.P., Nakamura, H., Ogane, K., Ohneiser, C., Richter, C., Robinson, R., Rohling, E.J., Romero, O., Sawada, K., Scher, H., Schneider, L., Sluijs, A., Takata, H., Tian, J., Tsujimoto, A., Wade, B.S., Westerhold, T., Wilkens, R., Williams, T., Wilson, P.A., Yamamoto, Y., Yamamoto, S., Yamazaki, T., and Zeebe, R.E., 2012. A Cenozoic record of the equatorial Pacific carbonate compensation depth. Nature, 488(7413):609-614. http://dx.doi.org/10.1038/nature11360

Reagan, M.K., Ishizuka, O., Stern, R.J., Kelley, K.A., Ohara, Y., Blichert-Toft, J., Bloomer, S.H., Cash, J., Fryer, P., Hanan, B.B., Hickey-Vargas, R., Ishii, T., Kimura, J.-I., Peate, D.W., Rowe, M.C., and Woods, M., 2010. Fore-arc basalts and subduction initiation in the Izu-Bonin-Mariana system. Geochemistry, Geophysics, Geosystems, 11(3):Q03X12. http://dx.doi.org/10.1029/2009GC002871

Reymer, A., and Schubert, G., 1984. Phanerozoic addition rates to the continental crust and crustal growth. Tectonics, 3(1):63-77. http://dx.doi.org/10.1029/TC003i001p00063

Richter, C., and Ali, J.R., 2015. Philippine Sea Plate motion history: EoceneRecent record from ODP Site 1201, central West Philippine Basin. Earth Planet. Sci. Lett., 410:165-173. http://dx.doi.org/10.1016/j.epsl.2014.11.032

Salisbury, M.H., Shinohara, M., Suetsugu, D., Arisaka, M., Diekmann, B., Januszczak, N., and Savov, I.P., 2006. Leg 195 synthesis: Site 1201-a geological and geophysical section in the West Philippine Basin from the 660$\mathrm{km}$ discontinuity to the mudline. In Shinohara, M., Salisbury, M.H., and Richter, C. (Eds.), Proceedings of the Ocean Drilling Program, Scientific Results, 195: College Station, TX (Ocean Drilling Program), 1-27. http://dx.doi.org/10.2973/odp.proc.sr.195.113.2006

Sasaki, T., Yamazaki, T., and Ishizuka, O., 2014. A revised spreading model of the West Philippine Basin. Earth, Planets and Space, 66(1):83. http://dx.doi.org/10.1186/1880-5981-66-83

Savov, I.P., Hickey-Vargas, R., D’Antonio, M., Ryan, J., and Spadea, P., 2005. Petrology and geochemistry of west Philippine basin basalts and early Palau-Kyushu arc volcanic clasts from ODP Leg 195, Site 1201D: implications for the early history of the Izu-Bonin-Mariana arc. Journal of Petrolology, 47(2):277-299. http://dx.doi.org/10.1093/petrology/egi075
Sclater, J.G., Jaupart, C., and Galson, D., 1980. The heat flow through oceanic and continental crust and the heat loss of the Earth. Reviews of Geophysics, 18(1):269-311. http://dx.doi.org/10.1029/RG018i001p00269

Seno, T., and Maruyama, S., 1984. Paleogeographic reconstruction and origin of the Philippine Sea. Tectonophysics, 102(1-4):53-84. http://dx.doi.org/10.1016/0040-1951(84)90008-8

Seton, M., Müller, R.D., Zahirovic, S., Gaina, C., Torsvik, T., Shephard, G., Talsma, A., Gurnis, M., Turner, M., Maus, S., and Chandler, M., 2012. Global continental and ocean basin reconstructions since $200 \mathrm{Ma}$. EarthScience Reviews, 113(3-4):212-270. http://dx.doi.org/10.1016/j.earscirev.2012.03.002

Sharp, W.D., and Clague, D.A., 2006. 50-Ma initiation of Hawaiian-Emperor Bend records major change in Pacific plate motion. Science, 313(5791):1281-1284. http://dx.doi.org/10.1126/science.1128489

Shibata, K., Mizuno, A., Yuasa, M., Uchiumi, S., and Nakagawa, T., 1977. Further K-Ar dating of tonalite dredged from the Komahashi-daini Seamount. Bulletin of the Geological Survey of Japan, 28:503-506.

Shipboard Scientific Party, 2002. Leg 195 summary. In Salisbury, M.H., Shinohara, M., Richter, C., et al., Proceedings of the Ocean Drilling Program, Initial Reports, 195: College Station, TX (Ocean Drilling Program), 1-63. http://dx.doi.org/10.2973/odp.proc.ir.195.101.2002

Stern, R.J., 2004. Subduction initiation: spontaneous and induced. Earth and Planetary Science Letters, 226(3-4):275-292. http://dx.doi.org/10.1016/j.epsl.2004.08.007

Stern, R.J., and Bloomer, S.H., 1992. Subduction zone infancy: examples from the Eocene Izu-Bonin-Mariana and Jurassic California arcs. Geological Society of America Bulletin, 104(12):1621-1636. http://dx.doi.org/10.1130/0016-7606(1992)104<1621:SZIEFT>2.3. $\mathrm{CO} ; 2$

Straub, S.M., 2003. The evolution of the Izu Bonin-Mariana volcanic arcs (NW Pacific) in terms of major elements. Geochemistry, Geophysics, Geosystems, 4(2):1018. http://dx.doi.org/10.1029/2002GC000357

Straub, S.M., Layne, G.D., Schmidt, A., and Langmuir, C.H., 2004. Volcanic glasses at the Izu arc volcanic front: new perspectives on fluid and sediment melt recycling in subduction zones. Geochemistry, Geophysics, Geosystems, 5(1):Q01007. http://dx.doi.org/10.1029/2002GC000408

Suyehiro, K., Takahashi, N., Ariie, Y., Yokoi, Y., Hino, R., Shinohara, M., Kanazawa, T., Hirata, N., Tokuyama, H., and Taira, A., 1996. Continental crust, crustal underplating, and low- $Q$ upper mantle beneath an oceanic island arc. Science, 272(5260):390-392. http://dx.doi.org/10.1126/science.272.5260.390

Sykes, L.R., 1970. Seismicity of the Indian Ocean and a possible nascent island arc between Ceylon and Australia. Journal of Geophysical Research, 75(26):5041-5055. http://dx.doi.org/10.1029/JB075i026p05041

Tani, K., Ishizuka, O., Ueda, H., Shukuno, H., Hirahara, Y., Nichols, A.R., Dunkley, D.J., Horie, K., Ishikawa, A., Morishita, T., and Tatsumi, Y., 2012. Izu-Bonin arc: intra-oceanic from the beginning? Unraveling the crustal structure of the Mesozoic proto-Philippine Sea plate [presented at the 2012 American Geophysical Union Fall Meeting, San Francisco, CA, 3-7 December 2012]. (Poster T11B-2569)

Taylor, B., and Goodliffe, A.M., 2004. The West Philippine Basin and the initiation of subduction, revisited. Geophysical Research Letters, 31(12):L12602. http://dx.doi.org/10.1029/2004GL020136

Taylor, S.R., 1967. The origin and growth of continents. Tectonophysics, 4(1):17-34. http://dx.doi.org/10.1016/0040-1951(67)90056-X

Uyeda, S., and Ben-Avraham, Z., 1972. Origin and development of the Philippine Sea. Nature, 240:176-178. http://dx.doi.org/10.1038/physci240176a0

Wallace, L.M., Ellis, S., and Mann, P., 2009. Collisional model for rapid forearc block rotations, arc curvature, and episodic back-arc rifting in subduction settings. Geochemistry, Geophysics, Geosystems, 10(5):Q05001. http://dx.doi.org/10.1029/2008GC002220

Whittaker, J.M., Müller, R.D., Leitchenkov, G., Stagg, H., Sdrolias, M., Gaina, C., and Goncharov, A., 2007. Major Australian-Antarctic plate reorganization at Hawaiian-Emperor Bend time. Science, 318(5847):83-86. http://dx.doi.org/10.1126/science.1143769 
Yamazaki, T., Takahashi, M., Iryu, Y., Sato, T., Oda, M., Takayanagi, H., Chiyonobu, S., Nishimura, A., Nakazawa, T., and Ooka, T., 2010. Philippine Sea plate motion since the Eocene estimated from paleomagnetism of seafloor drill cores and gravity cores. Earth, Planets and Space, 62(6):495-502. http://dx.doi.org/10.5047/eps.2010.04.001
Yuasa, M., and Watanabe, T., 1977. Pre-Cenozoic metamorphic rocks from the Daito Ridge in the northern Philippine Sea. Journal of the Japanese Association of Mineralogists, Petrologists and Economic Geologists, 72(6):241-251.

https://www.jstage.jst.go.jp/article/ganko1941/72/6/72_6_241/_pdf 